\title{
Persistence of the School Entry Age Effect in a System of Flexible Tracking
}

\author{
Patrick A. Puhani* \\ Andrea M. Weber
}

*Corresponding author:

Patrick A. Puhani

Leibniz University of Hannover Institut für Arbeitsökonomik

Königsworther Platz 1

D-30167 Hannover

Germany

Phone: $\quad++49-511-762-5619$

Fax: $\quad++49-511-762-8297$

E-Mail: puhani@aoek.uni-hannover.de 


\begin{abstract}
In Germany, the streaming of students into an academic or nonacademic track at age 10 can be revised at later stages of secondary education. To investigate the importance of such revisions, we use administrative data on the student population in the German state of Hessen to measure the persistence of school entry age's impact on choice of secondary school track. Based on exogenous variation in the school entry age by birth month, we obtain regression discontinuity estimates for different cohorts and grades up to the end of secondary education. We show that the effect of original school entry age on a student's later attending grammar school disappears exactly at the grade level in which educational institutions facilitate track modification.
\end{abstract}

\title{
JEL classification: I21, I28, J24
}

Keywords: Education, identification, regression discontinuity design, instrumental variables, relative maturity

Acknowledgment: This research was supported by the Anglo-German Foundation within the Economics and Politics of Employment, Migration and Social Justice project, which is part of the foundation's research initiative Creating Sustainable Growth in Europe. We are grateful to Christian Dustmann, Horst Entorf, Bernd Fitzenberger, Hendrik Jürges, Michael Lechner, Stephen Machin, Sandra McNally, Regina Riphahn, Claus Schnabel, Reinhold Schnabel, Kerstin Schneider, Uta Schönberg, and seminar participants of the Population Economics and Economics of Education groups of the German Economic Association for helpful comments. We also thank Hans-Peter Hafner of the Research Data Center (Forschungsdatenzentrum) of the statistical office of the state of Hessen for help with the Hessen administrative data. Björn Schumacher and Philip Yang provided excellent research assistance. All remaining errors are our own. 


\section{Introduction}

Recent research in education suggests that early human capital investment is crucial because of dynamic self-productivity and the complementarities of acquired skills and abilities (Cunha et al., 2006). This vital role of the path dependencies of human capital investment is especially obvious in sports. For example, tracking young players within a cohort into training groups by relative performance generates an advantage for relatively older and thus physically more developed players who consequently receive training of higher quality. As a result, the younger players within the same cohort fall behind while their relatively older peers are more likely to reach the highest level (Allen and Barnsley, 1993).

This observation is particularly important for the case of education in Germany, which is one of the few industrialized countries whose system of ability grouping or tracking physically segregates students after grade 4 (around age 10) into an academic or nonacademic track (for an overview of tracking systems, see Brunello and Chechhi 2006).

In this paper, we analyze a specific application in which educational institutions create a path dependency but allow for later corrections of the initially chosen track. First, we consider the effect of students' school entry age (which is linked to their relative maturity) on their secondary school outcomes. Second, using administrative data for six entire school entry cohorts in a major German state for five consecutive years, we observe the interaction of this effect in an early and rigorous secondary school tracking regime that primarily facilitates track revision six years after initial track choice. By focusing explicitly on track choice and by following several cohorts of students across different stages of secondary schooling, we provide evidence on the impact of a tracking design on educational outcomes.

Seminal work by Angrist and Krueger (1992) exploits a particular feature of the U.S. American school system by which birth quarter generates exogenous variation in the duration of mandatory schooling. Because compulsory schooling in the U.S. ends at age 16, students born earlier in the year enter school at a later age and thus have a shorter duration of 
compulsory schooling. Based on census data und using birth quarter as an instrumental variable for school entry age, the authors show that school entry age affects educational attainment. However, conditioned on school attendance beyond compulsory education, the school entry age effect disappears, which can be interpreted to mean that school entry age only influences potential school dropouts in the U.S. institutional context.

Subsequently, several methodologically similar papers examined school entry age effects for a broad spectrum of industrialized countries. Note that mandatory schooling in most countries is independent of school entry age, so that these studies identify the sole effect of (relative) school entry age. For instance, Bedard and Dhuey (2006), using data for 18 industrialized countries from the international TIMSS study, as well as additional data for the U.S. and Canada, estimate the effect of school entry age at the fourth and eighth grade using the birth month as an instrumental variable. They show that school entry age has a positive impact on test scores at these grade levels in almost all industrialized countries studied. Moreover, even though this effect is slightly smaller for the eighth grade than the fourth, the authors still find that in the U.S. an 11-month age difference increases the probability of college enrollment by 11 percentage points, a finding that contrasts with that of Angrist and Krueger (1992). Thus, the Bedard and Dhuey (2006) finding suggests a persistent relative age effect on educational outcomes. Likewise, Allen and Barnsley (1993) show that birth month (when it determines school entry age) affects schooling outcomes in Britain and Canada. Specifically, despite seeming to decline during the progression through school grades, the effects persist until the ninth grade. In British schools, birth quarter, in particular, has an impact on the school attended.

For Sweden, Fredriksson and Öckert (2006) find that starting school later has a positive effect on educational outcomes and on earnings later in life. However, the size of the effect diminishes over the lifecycle, and the earnings effects of a later school starting age may even be negative once the opportunity cost (lost earnings) of starting school (and hence 
working life) late are taken into account. By providing separate estimates of the school entry age effect for several birth cohorts, the authors show that the school entry age effect on years of schooling is larger for earlier cohorts, who were still subject to a school tracking system (similar to the current German one) that was replaced in the late 1960s with a comprehensive school system. Although Fredriksson and Öckert (2006) do not emphasize the relationship between tracking and the school entry age effect, to the best of our knowledge, their research, and analogously the Allen and Barnsley (1993) sports investigation, is the only study that provides evidence for the importance of tracking systems on the school entry age effect. ${ }^{1}$

Early school tracking is also criticized for generating or perpetuating inequality. For example, using tracking variations across countries, Brunello and Checchi (2006) find that early tracking reinforces initial differences (like family background effects) between students. Similarly, Dustmann (2004) shows that the German regime of early tracking generates high intergenerational correlation of track choice, while Hanushek and Wößmann (2006) reveal that countries with tracking increase the variance of student test scores (without raising the mean) relative to countries without tracking. Based on variations in tracking age between Swiss cantons, Bauer and Riphahn (2006) find that late tracking decreases inequality between students of high versus medium social background relative to early tracking. In addition, Meghir and Palme (2005) — in an evaluation of a Swedish policy reform that abolished school tracking, increased the duration of compulsory schooling, and changed the curriculum —observe that the earnings of individuals with high-skilled fathers fell but those of persons with low-skilled fathers rose following the reform. In contrast, Maurin and McNally (2007) find no evidence that easier access to grammar school (i.e., detracking) in Northern Ireland had a differential impact on students with different social backgrounds. Indeed, Pekkarinen (2005) even indicates that later tracking (at age 15 rather than 10) hurts

\footnotetext{
1 In Puhani and Weber [2007], we show that school entry age influences both test scores at the end of elementary school and track choice in the middle of secondary school. However, at the time of that study, the administrative data on vocational schools were not yet available, so we were unable to analyze track change
} 
boys with a nonacademic social background, an outcome that he relates to the timing of puberty.

As is apparent, none of these previous studies on tracking focuses explicitly on the possibility of correcting the tracking decision during the later years of secondary schooling, a modification that the German tracking system allows for, especially after grade 10. It should be noted, however, that this modification is bidirectional in that grammar school students have the option to downgrade by entering an apprenticeship while students from lower track schools may upgrade to a grammar school. Moreover, since the grammar school (i.e., college entrance) certificate $^{2}$ (Abitur) can also be obtained in vocational grammar schools (berufliches Gymnasium, Fachoberschule), determining whether the school entry age effect vanishes by the end of high school (grade 12 or 13 in Germany) requires observation of students in both general and vocational schools. As only the state of Hessen has provided us with all the required information on students in both types of schools, ${ }^{3}$ we focus on analyzing the effects for students in this state.

Specifically, we show that even though school entry age has a causal impact on track choice in fifth grade, this effect disappears six years later (in grade 11) because of the possibility of track revision. Such revision occurs mostly through track upgrading, which is to a large extent facilitated by the specialized (vocational) grammar schools that emerged from Germany's traditional system of vocational education. Thus, unlike previous research on the school entry age effect, our work reveals that the institutional design of the tracking regime not only generates but, once track choice can be revised, eliminates the school entry age effect on choice of track. Notably, whereas a later school entry age has a persistent effect on the track attended up to the tenth grade, the possibility of revising track choice at the eleventh grade eliminates this effect, with no systematic differences between boys and girls.

after grade 10, which turns out to be a crucial feature of the tracking system. Neither could we follow cohorts over time, because only one cross section of administrative data on general schools was available.

${ }^{2}$ This certificate is equivalent to a high school diploma in the U.S. 
Thus, it is institutional design — not time spent in school— that is responsible for the elimination of the school entry age effect.

This paper is structured as follows. Section 2 describes the administrative datasets for the state of Hessen, beginning with stylized facts drawn from the database and followed by a short overview of key institutional features of the Hessen school system as they compare to Germany as a whole. This discussion gives specific emphasis to the observed transitions between school tracks that are crucial to the present analysis. Section 3 outlines the empirical strategy for estimating the causal impact of school entry age on track attended, the results of which are presented and discussed in Section 4. Section 5 concludes the paper.

\section{Institutional Facts and the Administrative Data Source}

\subsection{School Tracking}

In general, tracking in Germany means that at a relatively early point in their educational career (fourth grade, age 10), students are streamed into three types of secondary school. Thus, in Germany, unlike the U.S., tracking implies the physical segregation of students into different schools. The underlying rationale is that a student's proficiency and elementary school performance will determine the choice of secondary school track. However, in practice, it is parents that primarily decide on their children's educational pathway. As a result, the German tracking system tends to produce low intergenerational mobility (Dustmann, 2004).

Supposedly, the most proficient students attend the highest secondary track, the Gymnasium (comparable to the traditional British grammar school), which lasts for nine years and prepares students for tertiary studies at academic institutions like three- or fouryear colleges and universities (the equivalent of the former British polytechnics and

\footnotetext{
${ }^{3}$ Among the 16 German states, Hessen, which includes the city of Frankfurt, has the fifth largest population and the seventh largest area.
} 
universities). ${ }^{4}$ Alternatively, lower and intermediate level secondary school tracks lasting five or six years are provided by Hauptschule (lower secondary schools) or Realschule (intermediate secondary schools), respectively. Education at these schools is supposedly less academic and more vocational than that of the grammar school and typically prepares students for apprenticeships, which implies subsequent part-time secondary education at vocational schools. The conceptual differences between the lower and intermediate level vocational tracks are small: students in the lower level track may simply stay another year to obtain the same certificate as students in the intermediate track, and recent tendencies even combine the two. Therefore, in this paper, we distinguish primarily between a grammar or nongrammar (i.e., vocational) track. In addition, the modern German school system includes comprehensive schools (Gesamtschule), developed as an alternative to the three traditional institutions.

To illustrate the importance of this tracking system to educational outcomes, Table 1 displays the shares of different school types attended in eighth grade during the 2005/2006 school year. The shares of the three traditional tracks range between one fifth for the lower level secondary schools to one third for the grammar schools, while about 15 percent of all German students attend comprehensive schools. The distribution for the West German state of Hessen (the focus of this study) is representative of the pattern for Germany as a whole, although compared to the average West German state, Hessen's proportion of comprehensive school graduates is relatively high $(15,15$, and 9 percent in Hessen, Germany, and West Germany, respectively). In fact, there is a long tradition of comprehensive schools in Hessen, where there are two types of comprehensive school—integrated comprehensive schools (integrierte Gesamtschule) that are truly comprehensive (i.e., nontracked) and cooperative comprehensive schools (kooperative Gesamtschule) that facilitate track modification by offering all tracks within one institution.

\footnotetext{
${ }^{4}$ Recently, there has been a tendency to shorten the traditional grammar school duration to eight years.
} 
In addition, Hessen is known for the flexibility of its secondary school system. That is, some Hessen schools offer support stages (Förderstufe) that provide comprehensive education during the fifth and sixth grades, thereby delaying tracking for two years. Hence, these children are given two more years to mature before reaching an appropriate tracking decision. According to our calculations from the administrative data, nearly 30 percent of all fifth graders in Hessen attend these delayed tracking schools.

Besides the comprehensive institutions, Hessen's tracking system includes two other important sources of flexibility. First, according to school law, students may modify track selection in all grades and all types of secondary school; however, in practice, such modification is complicated because school curricula differ and the school from which the student is transferring must agree to the transfer. Nonetheless, the tracking system potentially provides further flexibility in that students may correct their initial choice by deciding after graduation from a lower or intermediate secondary school to continue their education at either a general or a vocational grammar school.

This term "vocational grammar school" may sound contradictory, but it can be explained by Germany's vocational educational tradition. Stemming partly from the medieval guild and inn system, since the Bismarck period and Germany's rise as an industrial power, this tradition has expanded through the creation of higher technical (engineering) and business administration schools. Subsequently, other schools also developed that specialized in such disciplines as agricultural studies, social studies, health, or nutrition. In the 1960s and 1970s, some such schools became colleges (Fachhochschule) or technical universities (Technische Universität). It is therefore logical that since the 1960s, the vocational stream has developed its own grammar schools. There are two such types, namely vocational grammar schools leading to general college/university access (berufliches Gymnasium) and lower-level vocational grammar schools leading only to college access (Fachoberschule). Note that the equivalence of general vocational grammar school certificates to those from 
general grammar schools is crucial because in Germany's state-run university system,

colleges/universities usually cannot select students according to their own criteria.

\subsection{Administrative Student-Level Data for the State of Hessen}

In Germany, the states are responsible for the school system and therefore also for collecting administrative data on schools. Nonetheless, only recently have most states begun amassing the student level data that are of special interest to empirical researchers. ${ }^{5}$ This present study draws on five waves each of two sets of administrative data from the state of Hessen $^{6}$ that cover the school years 2002/2003 through 2006/2007. The first dataset includes the population of students in general primary and secondary education; the second, that of students in vocational (secondary) education. Whereas both datasets are necessary to profiling secondary education students in the state, the vocational dataset is particularly important because it registers graduates from the lower and intermediate level schools. These include students who continue secondary education at vocational grammar schools to earn the college/university entrance certificate (Abitur) and students in standard vocational schools (e.g., those in apprenticeships who must spend about two days per week at school). Therefore, not only is this present study the first (to our knowledge) to draw on the newly available vocational school data, ${ }^{7}$ but combining these datasets allows us to observe the entire population, not merely a sample, of secondary education students in Hessen.

The information contained in the Hessen administrative data is exceptionally valuable for analyzing the effects of school entry age until the end of secondary schooling. For example, the data waves can be used to examine the development of school entry age effects over school entry cohorts and grades (as estimated from annually available individual

\footnotetext{
Except for the state of Thüringen, which began gathering some individual information on general primary and secondary schools in 1992, no other states collected such data before 2002 (or even later in most cases).

6 In 2006, we contacted state statistical offices nationwide but at that time were denied access to the data in all states except Hessen. More recently, however, more states have been making administrative data on the general education system available. However, these data do not include students in vocational schools, as observed for Hessen and needed for the present study.

7 The separation of these two administrative datasets also stems from the history of the educational system in Germany.
} 
information). Nonetheless, in some cases, the data for vocational schools do not identify grade information. Therefore, because such information is completely missing for the 2002/2003 wave, we group students by school entry cohort and follow these cohorts over time, a technique that is equivalent to following cohorts across grades if students do not repeat or skip them (see Section 4 for an approximated grouping of students by grades).

The different cohorts and grades studied are summarized in Table 2, which shows that (ignoring grade repetitions and grade skipping) the cohort of students entering school in 1998 (cohort 1 in the table) is in fifth grade by the 2002/03 school year and can be tracked up to ninth grade in 2006. Similarly, the cohort of students that started first grade in 1993 (cohort 6) has reached the tenth year of schooling in the 2002 data wave and can be tracked up to the thirteenth year (when some students are still in general schools but others are in vocational schools). Since these data cover all students in secondary education in the state of Hessen, the number of observations is relatively high, around 60,000 individuals per cohort per school year. It should be noted, however, that individuals who leave the school system drop out of our dataset. Given that Hessen's school law requires students to attend at least nine years of general schooling plus, for those not attending grammar school, two or three years of vocational schooling (depending on the length of the apprenticeship chosen), those dropping out of the data before the thirteenth grade will generally not be students on the grammar school track (see also footnote 20). Such a student is typified by an individual who completes the lowest secondary track after ninth grade and a two-year apprenticeship after eleventh grade. Students may also drop out after the tenth grade if they are not doing an apprenticeship.

Accordingly, when estimating the effect of school entry age on track choice, the absence of some nongrammar school students from the eleventh grade data and, most especially, the twelfth and thirteenth grade data is a result of track choice and therefore an 
outcome. Hence, we add these missing observations from grades 11, 12, and 13 back into our cross sections by simulation (see Section 3.3).

The following variables are collected for each student: grade level and school type, grade level and school type in the previous school year, region, gender, nationality, month and year of birth, and month and year of school entry. Because there is no person identifier across years, we do not have panel data; however, based on the previous school type variable, we can retrospectively observe changes in track. This information on previous track, gleaned by combining the administrative data on general and vocational schools and following cohorts in all educational tracks, provides insight into track modification that may be crucial for determining the long-term educational effects of school starting age.

Table 3 summarizes the entry and exit rates to and from the grammar school track, which, as previously explained, comprises both general (traditional) and vocational grammar schools. Entry rates are defined as the number of students entering grammar school (from a lower track level) in a given grade divided by the total number of students in grammar school in the previous grade. ${ }^{8}$ Exit rates are defined as the number of students leaving grammar school in a given grade divided by the total number of students in grammar school in the previous grade.

As regards comprehensive schools, it may be hard to judge whether these students can be categorized into the grammar school category. However, the data classify students in cooperative comprehensive schools according to their respective tracks within the school (see Section 2.1). For students in integrated comprehensive schools (i.e., those without streaming), we assume that they are not at the grammar school level. In fact, information provided by the Federal Statistical Office indicates that only 7 percent of students in integrated comprehensive schools attain a grammar school certificate, partly because many of

\footnotetext{
This definition of entry rate makes the difference between the entry rate and the exit rate equal to the rate of increase of students in the grammar school track. It should also be noted that as defined the entry rate may in theory exceed 1 .
} 
these schools only provide education until tenth grade. Hence, measuring integrated comprehensive schools as lower track when in or below tenth grade seems justified.

As shown in Table 3, the entry rate for the 1998 school entry cohort amounts to 9 percent, while between school years 2002/03 and 2003/04 (corresponding to the time when students have attained 5 and 6 years of schooling respectively), 2 percent of students previously in the general grammar school track decided to switch to a lower track. ${ }^{9}$ Switching rates are especially high between the sixth and seventh year of schooling (the entry rate is between 16 and 22 percent for the observed cohorts) because in some Hessen schools support stages allow deferral of tracking until grade 6 (age 12). Similarly, students in their eleventh year of schooling show relatively high entry rates (44-45 percent) to the grammar school track level because graduates from the intermediate or lower level school tracks may decide to continue education at any type of grammar school (e.g., the vocational grammar school) to seek a college/university entrance certificate. ${ }^{10}$ The fact that grammar school entry rates also seem relatively high (at 17 percent) between the eleventh and twelfth grades results from the grouping of students according to school entry year rather than actual grade levels. If we attempt to group students by grade attended (which is difficult because of partially missing information), we obtain grammar school entry rates of around 73 percent between the tenth and eleventh grades and only 6 percent between the eleventh and twelfth grades. Hence, track upgrading seems related to institutional flexibility in the school system after the tenth grade.

Given our central research problem of the effect of school entry age on track level as students progress through the secondary school system in the German state of Hessen, any relationship between track mobility and school entry age would be of particular interest. However, prior to any empirical discussion of such a relationship, the following section outlines our regression discontinuity design approach to identifying the effect itself.

\footnotetext{
9 Entry rates may also include students moving to Hessen from another German state, which cannot be distinguished in our data. However, as outlined in footnote 17, migration in these age groups is small.

${ }^{10}$ Graduates of the lower secondary track must take one year at the intermediate level before attending grammar school.
} 


\section{Identification of School Entry Age Effects on Track Level}

\subsection{Implications of the Hamburg Accord and Discretion in Track Choice}

As in most other OECD countries, in Germany the school entry age is effectively assigned by law. Moreover, even though each German state has its own school law, there is a high degree of coordination between states. This coordination resulted in the Hamburg Accord, in force since 1964, which dictates that children in all German states should start school in August of a given year in which they turn six years of age before the end of June. Children turning six in the second half of the calendar year (i.e., between July and December) are supposed to wait until the following year before entering school. Thus, the Hamburg Accord generates a variation in the assigned school entry age between 6.08 and 7.08 years of age and, for children born directly around the cut-off date (June 30/July 1), a difference in school entry age of one year.

In addition, the actual school entry age can deviate from the assigned age due to parental discretion. For example, Article 58 of the Hessen school law explicitly allows for such a deviation: "Children who turn 6 years of age after June $30^{\text {th }}$ may enter school [in the same calendar year] by parents' application. The decision is made by the school principal with consideration of the school doctors' advice." ${ }^{\prime 11}$ However, students can enter school not only at an earlier-than-assigned age but also at a later one: “... children who do not have the required physical, intellectual, or mental status of development for attending school may be held back from attending ... school for one year by application of the parents or the school principal. .." In addition, the Hessen school law allows children to enter school later than assigned by the Hamburg Accord if their knowledge of German is insufficient, a decision that can be made by the school principal after consulting the parents.

Figure 1 displays the assigned and theoretical school entry age, as well as the probability to attend grammar school, by birth month for all the school entry cohorts during

\footnotetext{
${ }^{11}$ Here, and subsequently, we provide our own translation from the original German text.
} 
the 2005/2006 school year. As the figure shows, children born in June (who are supposed to enter school at age six) tend to enter school later than assigned, whereas children born in July (who are supposed to enter school at age seven) tend to enter earlier. In addition, within the share of students who deviate from their assigned school entry age, the closer a student's birth month to the cut-off date, the larger the deviation. Moreover, not only does the actual school entry age based on birth month jump upward between June and July (albeit not to the same degree as assigned by the Hamburg Accord), so too does probability to attend grammar school. This latter suggests that school entry age drives track choice, a conjecture that is formally tested in Section 4.

Given the flexibility of the entry age regulation, it is not surprising that the distribution of actual school entry ages is wider than that of assigned entry ages. ${ }^{12}$ As shown in Figure 2, entering school a year earlier or later than assigned is quite common in Hessen (and in other German states). As only the month and year, but not the birth date, are provided in the data, the assigned school entry age as measured varies between 6.17 and 7.08 . In the cohorts for the 2005/06 school year, 21 percent entered school early (i.e., below the age of 6.17) while about 16 percent entered late (i.e., after the age of 7.08).

The specified exceptions to the school entry rule suggest that the actual school entry age is probably endogenous, implying that even if birth month and thus assigned school entry age were randomly assigned across children, the actual school entry age would correlate with the child's proficiency. In particular, the regulations allow comparatively less proficient or disadvantaged children to enter school later. Similarly, ambitious parents can have their children enter school at a younger age if they convince the school principal, which means that more proficient children are likely to enter school at a younger age than that assigned by the Hamburg Accord.

\footnotetext{
${ }^{12}$ This flexibility exists in similar forms in virtually all the school laws of German states. Only Berlin is somewhat less flexible in that it requires children who turn six years of age in a calendar year to enter school in that year (making deferral impossible). Bavaria also plans to shift the cut-off date. These deviations from the end-of-June cut-off were enabled by the Hamburg Accord becoming less binding after 1997.
} 
This possibility of noncompliance with the Hamburg Accord makes it impossible to estimate the effect of the school entry age on school track level using simple correlations or ordinary least squares regressions (OLS). In other words, if we define $\beta_{1}$ to be the effect of school entry age $a$ on track level $y$, an OLS regression in the form of equation (1) will produce a biased estimate of $\beta_{1}$, because we have to expect that $E(\varepsilon \mid a) \neq 0$.

$$
y_{i}=\beta_{0}+\beta_{1} a_{i}+\beta_{2} x_{i}+\varepsilon_{i}
$$

More precisely, we expect the correlation between school entry age $a$ and the unobserved skill component $\varepsilon$ to be negative, generating downward bias in the estimate of $\beta_{1}$ because of reverse causation. In other words, less proficient children-who are also less likely to choose the grammar school track — tend to enter school at a later age.

Only if the vector of control variables $x$ were to contain all variables that drive the selection of both early or late school entry and track level would an ordinary regression (or simple discrete choice model) of track level on school entry age be meaningful. However, in most applications, we cannot be certain that all these variables are addressed. Moreover, the German administrative data for the state of Hessen provides few social-background variables and contains no test scores. ${ }^{13}$ Therefore, we cannot rely on OLS regression to estimate the effect of school entry age on track level.

\subsection{Exogenous Variation in Assigned School Entry Age}

Because of the endogeneity of the actual age of school entry, we consider two instrumental variable strategies to estimate the effect of school entry age on track level. First, we use the variation in assigned school entry age to construct a two-stage least squares estimator in which the assigned entry age acts as an instrument. More specifically, the Hamburg Accord generates an assigned school entry age $z_{i}$ for each student $i$, based on the student's birth month $b_{i}$ : 


$$
z_{i}=Z\left(b_{i}\right)=\left\{\begin{array}{l}
\frac{(72+8)-b_{i}}{12} \text { if } 1 \leq b_{i} \leq 6 \\
\frac{(84+8)-b_{i}}{12} \text { if } 6<b_{i} \leq 12
\end{array}\right.
$$

where, for example, $(72+8)-b_{i}$ indicates the school entry age (measured in months because the birth day is not given) for children born between January and June.

The first stage of the two-stage least squares estimator regresses the actual school entry age $a_{i}$ on the exogenous instrument $z_{i}$ and on other possibly exogenous characteristics $x_{i}$. In an OLS estimator, by definition, this first-stage regression splits the variation in the actual school entry age into (i) an exogenous component $\hat{a}_{i}$, driven by the Hamburg Accord assignment rule $Z(\cdot)$ (and other characteristics $x_{i}$ ) and (ii) an endogenous component $\hat{\eta}_{i}$, which is uncorrelated with $\hat{a}_{i}$ :

$$
\begin{aligned}
a_{i} & =\hat{\gamma}_{0}+\hat{\gamma}_{1} z_{i}+\hat{\gamma}_{2} x_{i}+\hat{\eta}_{i} \\
& =\hat{a}_{i}+\hat{\eta}_{i}
\end{aligned}
$$

The estimated first-stage coefficient $\hat{\gamma}_{1}$ indicates the degree of compliance with the Hamburg Accord assignment rule. This compliance drives the variation in the exogenous component of school entry age. As shown in Imbens and Angrist (1994), the instrumental variables estimator identifies the effect of interest for assignment rule compliers. ${ }^{14}$ Equivalently, the second-stage regression of track level $y$ on the exogenous component of school entry age $\hat{a}$ identifies the effect of school entry age on track choice for the group of students that would

\footnotetext{
${ }^{13}$ The administrative data for other German states is identical in this respect.

${ }^{14}$ Imbens and Angrist (1994) consider the case in which both the instrument and the impact variable are binary. In this case, $\hat{\gamma}_{1}$ would be a consistent estimate of the share of compliers in the population even though no single observation can be identified as a complier. In our application, the situation is slightly more complicated because each person can vary the age at school entry discretely by one or more years in either direction. Thus, the estimate $\hat{\gamma}_{1}$ is also influenced by students who would generally enter school too early but who would enter at age five (rather than six) if born in June and at age six (instead of seven) if born in July. As only 6 percent of students enter school very early (at age five) or very late (at age eight), we expect $\hat{\gamma}_{1}$ to be roughly equal to the share of Hamburg Accord compliers in the population of June- or July-born children.
} 
change their school entry age if their birth month (and hence their assigned school entry age defined by the Hamburg Accord) were hypothetically varied.

The question then arises of how representative this local average treatment effect (i.e., the effect for compliers with the Hamburg Accord; Imbens and Angrist, 1994) is for the population as a whole. Empirically, this question cannot be answered without further assumptions because individual complier status cannot be determined from the data and because such assumptions are needed for identification of the average treatment effect in the population.

The control function approach discussed in Garen (1984) and Card (2001) proposes a random coefficients model that assumes the deviation of the school entry age effect from the average treatment effect for an individual to be a linear function of the residual of the first stage equation; that is, a linear function of the amount of noncompliance. However, we believe that this assumption is too strong for our application because of the symmetry restriction - that is, late entry benefits those entering school too late in the same linear way as it would have harmed those entering too early. Nonetheless, we did produce control function estimates (not shown), which were only slightly larger than (and in some cases identical to) the local average treatment effects given here. Hence, we consider the local average treatment effect to be an informative parameter.

Alternatively, we may assess the direction of bias by comparing the estimates for cohorts with higher compliance to those for cohorts with lower compliance. However, such comparison (see the estimation results given below) gives no clear directional indication, even though theoretically those who comply with the school entry rule should be least affected by the school entry age, thereby biasing the local average treatment effect toward zero relative to the average treatment effect. ${ }^{15}$ Finally, it is worth noting that, although interpretations of local average treatment effects are debatable, we are less interested in the 
absolute size of the effect than the direction of change over time as students move to higher grade levels.

The second-stage estimator can be obtained using OLS regression for the following equation: ${ }^{16}$

$$
y_{i}=\beta_{0}+\beta_{1} \hat{a}_{i}+\beta_{2} x_{i}+\underbrace{\left(\varepsilon_{i}+\beta_{1} \hat{\eta}_{i}\right)}_{\tilde{\varepsilon}_{i}}
$$

If birth month, and therefore the instrument $z_{i}$, is completely random, no control variables $x_{i}$ are needed. Indeed including control variables that are not exogenous could even make the two-stage least squares estimator inconsistent. On the other hand, exogenous controls improve the estimator's precision. Therefore, as a robustness check, we have produced estimates with and without the gender, regional (county), and citizenship control variables. Due to robust results, the estimates with control variables are not shown below.

Because we cannot test whether birth month, and hence our instrument, is truly randomly assigned, we prefer a second identification strategy, the fuzzy regression discontinuity design (Hahn, Todd, and Van der Klaauw, 2001). Technically, this procedure amounts to applying the same two-stage least squares estimator described above but only to the population of students born close to the cut-off date (i.e., in June or July). Table 4 and Table A1 present the correlations between the instrument and the control variables of gender, region (county), and country of citizenship for two selected cohorts in all five school years for the discontinuity (June- or July-born) and full population, respectively. They show that the correlations are either zero or close to zero and at most 0.03 in absolute value, which tentatively indicates that, even though few socioeconomic characteristics are given in the administrative data, birth month (which drives the instrument) is random. Nonetheless, by focusing on the population of students born in June or July, we address any remaining doubts

\footnotetext{
${ }^{15}$ However, this theoretical assumption need not be true if the effect of age at school entry has opposite signs within the population of noncompliers. In this case, the direction of bias is undetermined.

${ }^{16}$ We obtain the correct standard errors using a two-stage least squares procedure in Stata.
} 
about the instrument's exogeneity (defined on the basis of birth month). This identification

strategy is also more convincing in terms of isolating other factors that might correlate with birth season and track choice. Results for the full population of students (born in any month of the year) are provided in the appendix.

\section{3 $\quad$ First-Stage Regressions}

Coefficients of the first-stage regressions for the population of students born in June or July are displayed in Table 5. Here, and in the following section, we show only the specifications without control variables because the estimates with and without control variables are almost identical. As mentioned in Section 2.2, a subpopulation of those students who do not choose the grammar school track drops out of the dataset at the eleventh, twelfth or thirteenth grade, depending on the type of school or apprenticeship chosen. Therefore, we simulate missing observations in these grades so that the number of observations is identical to those in the tenth year of schooling. Missing observations are always allocated to the nongrammar track because had these students sought a higher secondary diploma, they would be in the data. ${ }^{17}$ The allocation of the simulated observations to the birth months of June or July and to the school entry ages of six or seven is based on the number of missing observations in these cells for the eleventh through thirteenth year of schooling relative to the number of observations for the tenth year of schooling. ${ }^{18}$ The corresponding estimates for the

\footnotetext{
${ }^{17}$ In theory, the fall in the number of students might also be due to net out-migration from the state of Hessen. However, we find this explanation for the fall in the number of observations from the eleventh grade onwards implausible because the published net-migration rate for the age group 6-18 years in Hessen is -1 percent compared to +12 percent for ages $18-25$. We lose about 10 percent of the observations between the eleventh and twelfth grades. As students usually still live with their parents at these ages, it is unlikely that this loss of observations has anything to do with educational migration. It is also unclear what students in Hessen would gain by switching state borders in the twelfth and thirteenth grades (when again we lose some observations, most likely because of apprenticeship completion). The high net-immigration rate (over 12 percent) for ages 18-25 is probably driven by college/university students and young workers. Nor can the figures be explained by parental out-of-state migration because this latter would occur more evenly across cohorts in a given calendar year and because net-migration of age groups 25-40 and 40-50 is close to zero or -2 percent, respectively. As the loss of observations is evidently related to the student's grade level (or time in school), school dropout and apprenticeship completion are the only possible explanation for the reduced number of observations.

${ }^{18}$ For each birth month, the proportion of students entering earlier or later than the theoretical school entry age is held constant (relative to grade 10). For the simulated observations, we assume that those entering earlier (later) than their theoretical entry age always enter one year earlier (later).
} 
dataset observations only (i.e., exclusive of simulated observations) are given in the nonshaded area of the lower panel of Table 5 (as well as of the following tables). It should be noted, however, that we expect these estimates to be biased because dataset dropout is not random but rather results from having chosen a lower track.

Estimates for the first stages of the two-stage least squares regressions are provided by cohort and school year together with the F-statistics, which if below 10, indicate potential weak-instrument problems (Staiger and Stock, 1997; Stock, Wright, and Yogo, 2002). If the cohorts change little over time - for example, through migration across state borders (see footnote 17) - the first-stage coefficients should not vary much by school year within cohorts. However, first-stage coefficients might vary across cohorts if compliance behavior were to change from year to year. As shown in the first column of Table 5, for the 2002/03 school year, there is indeed some variation in the degree of compliance across cohorts. Whereas the 1995 school entry cohort (cohort 4 in the table) shows the lowest compliance with a first-stage coefficient of 0.31 , the 1997 school entry cohort (cohort 2) shows the highest with a coefficient of 0.41 . These figures reflect the fact that compliance with the assigned entry age is much lower in Germany than in Scandinavian countries like Sweden and Norway (Fredriksson and Öckert, 2006; Strøm, 2004), which can be explained by the opt-out clauses in the German school laws. Nonetheless, none of the first-stage F-statistics point to a weak instrument problem. In the full population (see Table A2), the degree of compliance is mostly somewhat higher than in the discontinuity samples, a difference resulting from the behavior of students born in months other than June or July. In the firststage estimates within cohorts across school years, variations in the point estimates are, as expected, mostly minor. In addition, the number of observations per cohort seldom varies by more than a percentage point. 


\section{School Entry Age Effects on Track Attendance in Secondary School}

\subsection{Ordinary Least Squares Regressions}

As argued in Section 3.1, we expect the correlation between school entry age and track choice to be driven by an overlap of the effect of school entry age on track choice and a selection effect. Table 6 presents the bivariate OLS estimates for attending a general or vocational grammar school and school entry age. Separate estimates are provided by school entry cohort and school year.

As the table shows, from the sixth to the tenth grade (the grey-shaded areas), all estimates, without exception, are negative and statistically significant. ${ }^{19}$ Hence, the correlation between school entry age and attending a grammar school is unambiguously negative in the middle of secondary school. In addition, a representative estimate indicates that those students who enter school at age seven have a probability of attending grammar school that is 11 percentage points lower than that of students entering school at age six. Moreover, including gender, regional, and country of origin controls into the regression leads to only small changes in the estimates (not shown), with a tendency for the point estimate to become smaller in absolute value. This decrease in the absolute value of the OLS estimate is indicative of a correlation between the actual school entry age and the socioeconomic characteristics that lead to a downward bias in the OLS coefficients (see Section 3.1).

\footnotetext{
${ }^{19}$ For the 1998 school entry cohort in 2002/03 (supposed to enter the fifth grade), the estimate is comparatively small in absolute value because some students-who either repeated a grade or entered school through a special preschool (Vorklassen) — are still in primary school. This preschool (grade 0), effectively leads to a five-year (rather than four-year) elementary school period. Because we group students by school entry year, those who entered such a preschool in 1998 are still in elementary school (i.e., fourth grade) by 2004/2005, which implies that they cannot be part of the grammar school track. This situation causes an upward bias in the OLS estimate because some young starters (school entry age is registered irrespective of whether the grade entered is 0 or 1) are not in the grammar school track in the 2002/2003 school year. Excluding all those in elementary school changes the OLS estimate to -0.13 - a similar value to that for the other grades up to the tenth. Since the data do not record whether a student entered school through preschool (which about 4 percent do), we are unable to handle this issue directly. However, because entry into preschool distorts the student grade allocations, in Section 4.3, we construct a robustness check that groups students by actual grades attended.
} 
Interestingly, in the eleventh year of schooling the OLS estimates differ markedly from those up to the tenth year of schooling, with point estimates between zero and -4 percentage points. ${ }^{20}$ This is when upward mobility into the grammar school track is particularly high (see Table 3) and late entrants, likely to be a select group of students with less innate ability, enter the higher track. This latter suggests that such mobility may be affecting the correlation between school entry age and track level. As noted in Section 3.1, school entry age regulations allow students without the required level of proficiency to defer school entry, which, assuming that these students have less innate ability, will generate a negative correlation between school entry age and grammar school attendance that is not causal. The disappearance of this correlation at eleventh grade suggests that track upgrading after tenth grade provides grammar school education to less talented students, an argument often made by conservative political circles who want to preserve rigorous tracking. In contrast, the political left, which favors institutional flexibility, argues that track upgrading helps students with innate ability but disadvantaged backgrounds.

To test these assumptions, we carry out a causal analysis of school entry age using regression discontinuity and instrumental variable estimation. We find that the possibility of track revision not only opens the gates of grammar schools to less talented students (as suggested by the OLS results) but also corrects the school entry age effects. Hence, as only a causal analysis can show, it benefits some able students (there should be no systematic innate differences between June- and July-born children) who were disadvantaged by their relatively young age at the time of initial track selection (at age 10).

\footnotetext{
${ }^{20}$ The coefficients turn significantly negative again 12 and especially 13 years after school entry, possibly because some vocational grammar schools (Fachoberschule) finish after twelfth grade. Therefore, assigning all simulated observations to the lower track may be problematic. Nonetheless, our main results are unaffected by this problem because the change in the regression discontinuity estimates between the twelfth and thirteenth grades are not relevant for the focus of this study.
} 


\subsection{Causal Effects: Regression Discontinuity Estimates}

The regression discontinuity design estimates (two-stage least squares based on the population of students born in June or July) are provided in Table 7. It is remarkable that, in contrast to the OLS estimates, all estimates for up to the tenth year of schooling (grey shaded areas) are positive and different from zero in terms of statistical significance. The negative OLS estimates are therefore heavily affected by reverse causation and strongly biased downward.

As the table shows, the regression discontinuity point estimates up to the tenth year of schooling range between 0.08 and 0.19 , but the variation in the estimates is larger between than within cohorts (e.g., the range is between 0.11 and 0.16 for the 1998 school entry cohort and between 0.08 and 0.10 for the 1997 school entry cohort). The median estimate in the grey-shaded region (fifth to tenth grade) is 0.13 , implying that the effect of entering school at age seven instead of age six increases the probability of attending grammar school by 13 percentage points, which is large given that only slightly over a third of all students attend grammar school (this effect comes into full force for a complier with the Hamburg Accord whose birthday is changed from June 30 to July 1). ${ }^{21}$ The standard deviations of these estimates lie between 2 and 3 percentage points. Including additional control variables changes the point estimates only slightly and in all cases by less than one standard deviation of any estimate. The corresponding estimates based on the full population of students (see Table A4) are mostly only a few percentage points higher than those for the population of students born in June or July (see Table 7).

From the two grade transitions for which the tracking system exhibits the largest mobility - that is, from the sixth to the seventh grade and the tenth to the eleventh gradethere emerges a clear pattern. First, the support stages provided by some Hessen schools do not lead to a distinct change in the point estimate of the school entry age effect between the

\footnotetext{
${ }^{21}$ Estimates at the mean obtained from probit instrumental variable models are almost numerically identical to the linear probability model estimates presented here.
} 
sixth and seventh year of schooling (cf. the estimates for the 1997 and 1998 school entry cohorts in Table 7). Hence, the institutional mobility offered by these support stages in the form of a deferred track choice at the age 12 instead of 10 does not attenuate the school entry age effect on track choice.

In contrast, the possibility of correcting the tracking decision after tenth grade has major consequences. First, none of the point estimates of the school entry age effect are significantly different from zero for students having attained 12 years of schooling, and only two out of four are significant when students have attained 11 years of schooling. Indeed, the decreases in the point estimates between 10 and 11 years of schooling are very large and range between 5 and 13 percentage points, depending on the school entry cohort. ${ }^{22}$ In the full population of students (see Table A4), the results are very similar: the point estimates drop between 6 and 13 percentage points between 10 and 11 years of schooling, and 12 years after school entry, there are no longer any significantly positive effects.

Despite not having panel data, we can examine the track attended in the previous school year. As already shown in Table 3, changes in school track are mostly upgrades to (general or vocational) grammar schools and occur predominantly after 10 years of schooling. Therefore, to document the effect of school entry age on track upgrade to grammar school directly, in Table 8 we present two-stage least squares estimates with track upgrade as the outcome variable (based on the population of students born in June or July; the results for the full population of students are given in Table A5).

According to these estimates, the German tracking system is more likely to allocate students who enter school at a relatively older age to the grammar school track after elementary school and does not reverse this decision until six years later. That is, the regression discontinuity estimate for five years of schooling (the upper left dark-shaded

\footnotetext{
${ }^{22}$ Even without simulating the observations lost in the eleventh to the thirteenth grade because of school dropout and completed apprenticeships, we still observe a large drop in the point estimates, although not as large as when the lost observations (which are a result of track choice) are taken into account (see the lower part of Table 7).
} 
figure) suggests that entering school at age seven instead of six increases the probability of entering grammar school in the fifth grade (when tracking begins) by 13 percentage points. As might be expected, these estimates correspond to those for track level given in Table 7. In the subsequent years (sixth to tenth year of schooling), the school entry age has barely any effect on track upgrading: the point estimates are close to zero (2 percentage points, maximum) and often insignificant. This finding is not surprising given that curriculum differences and other requirements make it difficult to change tracks during the middle of secondary school (see Section 2.1). However, when students enter their eleventh year of schooling, graduates from the nongrammar school track must decide whether to enter apprenticeship training (with ordinary vocational schooling) or move to a general or vocational grammar school. It is at this time that the German tracking system facilitates track upgrading.

As the estimates in Table 8 show, in the eleventh year of schooling, track upgrading is influenced by school entry age: students who entered school at a relatively older age are less likely to upgrade. In other words, students who entered school at a relatively young age (age six instead of seven) are more likely to upgrade. Indeed, the point estimates indicate that entering school at age seven instead of six decreases the probability of upgrading to the grammar school track by between -4 and -8 percentage points. A year later, in the twelfth year of schooling, the effect is still between 0 and -3 percentage points, which adds up to an effect between -6 and -8 percentage points in each cohort. ${ }^{23}$ Comparing the effects of school entry age on track attendance and track upgrade (Table 7 and Table 8) shows thatdepending on the cohort— track upgrading explains more than half or almost all of the disappearance of the school entry age effect on attending grammar school. For the 1995 and 1993 school entry cohorts (cohorts 4 and 6, respectively, in the tables), a later school entry age also has a significant effect on track downgrade (results not shown), which-together 
with the Table 8 results on track upgrade - explains the size of the declines in the estimates presented in Table 7.

The finding of significant effects of school entry age on track attendance up until 10 or 11 years after school entry, as well as their subsequent elimination, raises the question of gender differences. In fact, our results suggest that compliance with the Hamburg Accord's rule on school entry age is very similar for boys and girls (the first-stage coefficients, not shown here, hardly vary between genders). So is the main result: in Table A6 and Table A7, we present two-stage least squares coefficients for men and women, respectively, born in June or July: these figures indicate no systematic differences between boys and girls. Rather, for both genders, there is a significant school entry age effect until 10 years after school entry, which becomes insignificant 12 years after school entry at the latest.

\subsection{The Influence of Institutions and Time on the School Entry Age Effect}

As shown in the previous section, students who were relatively young at school entry tend to move to lower tracks at about age 10 (when tracking begins) but tend to upgrade their track choice on attaining their eleventh year of schooling. Although it is striking that mobility occurs exactly when track change is institutionally facilitated, it is unclear whether institutions or simply time in school cause the systematic track upgrade by relatively young school entrants.

To address this question, we perform two different checks. First, it should be noted that throughout this paper we have grouped students by school entry year because the administrative data on vocational schools gives no direct information on grade attended (these data are entirely missing for the $2002 / 2003$ school year and for all years for certain types of schools). Nonetheless, as an initial probe for indications of any influence of either time or institutional type on the school entry age effect, we construct groupings of students by grade from the available data. If it is institutions that matter rather than years spent in

\footnotetext{
${ }^{23}$ The estimates without simulated missing observations (lower panel of Table 8 ) are lower in absolute value but
} 
school, once students are grouped according to actual grade rather than year of school entry, the reduction in the school entry age effect should be larger between the tenth and eleventh grade.

Second, we define alternative outcome variables by counting only (i) the general (i.e. traditional) grammar schools or (ii) the general grammar schools and the vocational grammar schools leading to general college/university entry (berufliches Gymnasium) as grammar track and coding (i) all vocational grammar schools or (ii) the lower-level vocational grammar schools only allowing college entry (Fachoberschule) as nongrammar track. Comparison of these results with those discussed in Section 4.2 reveals whether students are upgrading primarily through vocational or also through traditional grammar schools. If track upgrading occurs mostly in vocational (rather than general) grammar schools, it would be another indication for the importance of institutions (here, vocational grammar schools) in eliminating the school entry age effect. However, it also raises the question of the equivalence of different grammar school certificates (see below in this and in the following subsection).

Table 9 reports the regression discontinuity estimation results for the grouping according to grades. It should be noted again that we lose the first year (2002/2003), because the administrative data on vocational schools for this year does not include the required information. Therefore, to gauge whether it is the institutional type or number of years in school that matters more, the estimates based on grade grouping must be compared with those of the grouping by school entry cohort (Table 7). Specifically, we can compare the change in the effect of school entry age on attending grammar school between the tenth and eleventh grades for cohorts 3 to 5 (cohort 6 is only observed when students are already in the eleventh grade because we have no data on grades for the 2002/2003 school year). As the comparison between Table 7 and Table 9 clearly shows, the fall in age effect is much larger 
when students are grouped according to the actual grade attended rather than years since school entry. Indeed, whereas the median estimate for tenth graders is still between 0.12 and 0.13 , none of the estimates for the eleventh grade remain significant, with a maximum point estimate of 0.05 . The point estimates for the eleventh through thirteenth grades are similar and, without exception, insignificantly different from zero. It should also be noted that grouping students according to the year of school entry results in a somewhat more protracted drop in the school entry age effect, which is zero for all cohorts only 12 years after school entry (Table 7). However, given the results shown in Table 9, in which we group students by grade, the timing of the elimination of the school entry age effect can seemingly be explained by some students repeating a grade during secondary school and thus attending the eleventh grade in their twelfth year of schooling. ${ }^{24}$ In sum, the findings substantiate the view that the school entry age effect on track attendance is eliminated in the eleventh grade and that it is the institutional flexibility provided by the German education system after the tenth graderather than the student's personal maturity — that is responsible for the elimination of the school entry age effect on attending grammar school.

Further support for this view is given by the estimation results shown in Table 10 and Table 11, in which we check whether the elimination of the school entry age effect occurs through general (traditional) or more recently created vocational grammar schools. As indicated above, this is done by counting (i) only the former as grammar track and the latter as lower track (Table 10) or (ii) counting only general or vocational grammar schools leading to general college/university entry (Gymnasium and berufliches Gymnasium) as grammar track and lower-level vocational grammar schools only allowing college entry (Fachoberschule) as nongrammar track (Table 11). We find that all types of grammar schools are important in the elimination of the school entry age effect. As shown in Table 10, the school entry age effect on attending general grammar school diminishes in the eleventh year

\footnotetext{
${ }^{24}$ Two-stage least squares estimates of the effect of age at school entry on grade repetition (not shown here) are
} 
of schooling. However, it remains significant until 13 years after school entry, which suggests that, all else being equal, without the two types of vocational grammar schools, the school entry age effect would not completely vanish. Counting vocational grammar schools leading to general college/university entry into the grammar school track (Table 11) further decreases the school entry age effect in the eleventh year of schooling by between one and three percentage points depending on the cohort and school year considered. However, 12 years after school entry, the point estimates still remain significant at between 6 and 8 percentage points. Therefore, as a comparison with Table 7 shows, lower-level vocational grammar schools leading to college entry only (Fachoberschule) are important in making the school entry age effect insignificant (with point estimates between 0 and 5 percentage points). Hence, both general (traditional) and vocational institutions contribute to the elimination of the school entry age effect on the probability to attend grammar school.

To illustrate this issue further, Table 12 exhibits the distributions of school attended by birth month (June or July) twelve years after school entry for cohorts 4 through 6 . We distinguish between three types of grammar school and the nongrammar track. The grammar school types are general grammar school, vocational grammar school providing general college/university access (berufliches Gymnasium) and lower-level vocational grammar school providing only college access (Fachoberschule). Consistent with the results in Table 7, the probability to attend the nongrammar track is about equal between students born in June and July (depending on the cohort), but June-born students are less likely to attend general grammar school (significant for all cohorts) and more likely to attend the lower-level vocational grammar school (providing only college access; significant for cohorts 5 and 6).

\subsection{Grammar School Tracks and Wages}

The fact that the available data measure track attendance only until the end of secondary school raises two important questions. First, what impact does track attendance 
have on the labor market? Second, in what ways are different types of grammar schools economically, rather than formally, comparable? Because scientific use files of large labor force surveys in Germany provide no information on birth month, we cannot take the direct route and estimate the effects of birth month on wages. ${ }^{25}$ Rather, we use the 2004 German Socio-Economic Panel (GSOEP) and Mikrozensus (a one-percent census of the population, MZ) to estimate the difference in the return to holding a general grammar school certificate (awarded by general grammar schools and the vocational grammar schools called berufliches Gymnasium; these two types of grammar school cannot be distinguished in the data) and in the return to holding a certificate of a lower-level vocational grammar school granting college but not university entry (Fachoberschule). We start by regressing the log gross hourly wages (GSOEP) or log net hourly income (MZ) on a dummy variable that indicates any type of grammar school certificate. The only control variables are age and age squared (the population includes only West German workers aged 26 to 40 who attended school from the 1970s onwards, when the current German schooling system was already in place). As Table 13 shows, for men, the estimated return to completing grammar school (which potentially involves attending college/university, which is not controlled for in the regressions) amounts to 21 (GOESP) or 25 (MZ) percent; for women, it is 24 (GSOEP) or 26 (MZ) percent. Similar regressions with higher education as the outcome variable (not shown) suggest that grammar school completion raises the probability of obtaining a college/university degree by 51 (GSOEP) or 52 (MZ) percent for men and 48 (GSOEP) or 46 (MZ) percent for women.

As regards the question of returns to different types of grammar school, estimating similar hourly wage/income regressions as above, we test whether the labor market returns between the two types of grammar school certification differ (also shown in Table 13). For men, the difference in the return between a general college/university entrance certificate and

\footnotetext{
${ }^{25}$ The German Socio-Economic Panel (GSOEP) provides birth month but is too small in terms of sample size to
} 
that earned at the lower-level vocational grammar school is a statistically insignificant 3 percent in the GSOEP, but a statistically significant 8 percent in the large MZ dataset. For women, it is a statistically insignificant -1 percent in the GSOEP but a significant 11 percent in the MZ. ${ }^{26}$ Hence, younger school entrants seem to obtain grammar school degrees of lower quality, although the school entry age effect on obtaining any type of grammar school degree is zero according to our estimates in Table 7.

Although present discounted value comparisons for entering school at different ages are out of the scope of this study, the following back-of-the-envelope calculation can be made. From a comparison of Table 7 and Table 11, we retrieve that about 5 percent of all students who enter school at the age of six instead of seven obtain a lower quality grammar school degree (that is from the vocational grammar school type Fachoberschule). This costs them about 8 percent lower wages (in any year when they work). The expected wage loss when working is thus $0.05 \times 0.08=0.004$, which is less than half a percent. However, this cost comes with the benefit of entering the labor market a year earlier. Over a 40 -year working life, one year makes up 2.5 percent of life-time earnings (if the present discounted value of any year of work is assumed constant for simplicity). Although this calculation is rough, small changes to the assumptions will not change the conclusion that entering school a year later has higher costs than benefits from a purely financial point of view.

\section{Conclusions}

Based on administrative data on the student population in the German state of Hessen and a regression discontinuity design, we provide evidence for the effect of school entry age (relative maturity) on secondary school track attended. To this end, we present — to the best of our knowledge - the first empirical investigation to include administrative data on

\footnotetext{
analyze wage effects of birth month.

${ }^{26}$ The large discrepancy between the GSOEP and MZ results, especially for women, may be a result of the small sample size in the GSOEP (only 138 women are observed with a certificate of the vocational grammar school Fachoberschule). In addition, the outcome variable is measured differently (gross hourly wages versus net hourly income) in both data sets.
} 
individual students from both general and vocational schools in a German state. Specifically, we follow six different cohorts across time for five school years.

After fourth grade, the German educational system physically separates students into different secondary school tracks of which only the highest (grammar school) track allows access to tertiary college/university education. Nonetheless, especially after tenth grade, students can revise the original tracking decision. Specifically, students who have not attended grammar school may opt for a general (i.e. traditional) or vocational grammar school offering similar certificates. We show that this tracking system generates a statistically significant effect of school entry age on the probability of attending the highest track level until 10 years after school entry. A relatively young school entry age significantly decreases the probability of attending grammar school (by about 13 percentage points). However, the school entry age effect disappears 11 or 12 years after school entry, depending on the school entry cohort studied.

Additionally, we show the crucial role of vocational grammar schools, which account for about one half of the elimination of the school entry age effect (depending on the cohort studied). The other half is accounted for by general grammar schools accepting — after tenth grade — students who had previously attended lower tracks. For some cohorts, track downgrade also plays a part in the elimination of the school entry age effect because grammar school students may enter the vocational apprenticeship system after grade 10 without further requirements and without earning a higher level secondary certificate. In general, however, track upgrading after tenth grade — which, as the regression discontinuity estimates show, is affected by school entry age - is key to the elimination of the school entry age effect.

By grouping students both by the year at school entry and grades attended, we show that the school entry age effect is eliminated specifically after tenth grade rather than simply after a certain number of years in school. Hence, institutional design seems important for 
whether and when the school entry age effect is eliminated. Nonetheless, our findings do not prove that years of schooling plays no role at all; indeed, the institutional support stage, which allows deferral of the tracking decision for two years, does not change the impact of school entry age on the tracking decision.

In sum, our results support policies that facilitate correction of the school tracking decision sufficiently prior to the decision to attend college/university. In particular, we have shown that relatively young students — who, when June or July birth month is treated randomly, lag behind their peers only in relative maturity—are systematically more unlikely to select into grammar school. Although relatively young school entrants make up the gap in grammar track attendance due to upgrading to the grammar school track after tenth grade, they partially upgrade to lower quality grammar schools. Back-of-the-envelope calculations suggest slightly lower wages during working life entailed by starting school at age six rather than seven, but these costs do not seem to exceed the benefits of entering the labor market a year earlier. 


\section{References}

Allen, J. and R. Barnsley (1993): Streams and Tiers: the Interaction of Ability, Maturity, and Training Systems with Age-Dependent Recursive Selection, Journal of Human Resources 28: 649-659.

Angrist, J.D. and A.B. Krueger (1992): The Effect of Age at School Entry on Educational Attainment: An Application of Instrumental Variables with Moments from Two Samples, Journal of the American Statistical Association 87: 328-335.

Bauer, Ph. and R.T. Riphahn (2006): Timing of School Tracking as a Determinant of Intergenerational Transmission of Education, Economics Letters 91: 90-97.

Bedard, K. and E. Dhuey (2006): The Persistence of Early Childhood Maturity: International Evidence of Long-Run Age Effects, Quarterly Journal of Economics 121: 14371472.

Brunello, G. and D. Checchi (2006): Does School Tracking Affect Equality of Opportunity? New International Evidence, IZA Discussion Paper No. 2348.

Card, D. (2001): Estimating the Return to Schooling: Progress on Some Persistent Econometric Problems, Econometrica 69: 1127-1160.

Cunha, F., J.J. Heckman, L. Lochner and D.V. Masterov (2006): Interpreting the Evidence on Life Cycle Skill Formation. In: Hanushek E. and F. Welch (eds.): Handbook of the Economics of Education. Vol.1. Elsevier, Amsterdam: North-Holland: 697-812.

Dustmann, C. (2004): Parental Background, Secondary School Track Choice, and Wages, Oxford Economic Papers 56: 209-230.

Fredriksson, P. and B. Öckert (2006): Is Early Learning Really More Productive? The Effect of School Starting Age on School and Labour Market Performance, IFAU Working Paper No. 12.

Garen, J. (1984): The Returns to Schooling: A Selectivity Bias Approach with a Continuous Choice Variable, Econometrica 52:1199-1218.

Hahn, J., P. Todd and W. Van der Klaauw (2001): Identification and Estimation of Treatment Effects with a Regression-Discontinuity Design, Econometrica 69: 201-209.

Hanushek, E.A. and L. Wößmann (2006): Does Educational Tracking Affect Performance and Inequality? Differences-in-Differences Evidence Across Countries, Economic Journal 116: C63-C76.

Imbens, G.W. and J.D. Angrist (1994): Identification and Estimation of Local Average Treatment Effects, Econometrica 62: 467-475.

Maurin, E. and S. McNally (2007): Educational Effects of Widening Access to the Academic Track: A Natural Experiment, IZA Discussion Paper No. 2596.

Meghir, C. and M. Palme (2005): Educational Reform, Ability, and Family Background, American Economic Review 95: 414-424. 
Pekkarinen, T. (2005): Gender Differences in Educational Attainment: Evidence on the Role of the Tracking Age from a Finnish Quasi-Experiment, IZA Discussion Paper No. 1897.

Puhani, P.A. and A.M. Weber (2007): Does the Early Bird Catch the Worm? Instrumental Variable Estimates of Early Educational Effects of Age of School Entry in Germany, Empirical Economics 32: 359-386.

Staiger, D. and J.H. Stock (1997): Instrumental Variables Regression with Weak Instruments, Econometrica 65: 557-586.

Stock, J.H., J.H. Wright and M. Yogo (2002): Survey of Weak Instruments and Weak Identification in Generalized Method of Moments, Journal of Business and Economic Statistics 20: 518-529.

Strøm, B. (2004): Student Achievement and Birthday Effects, mimeograph, Norwegian University of Science and Technology. 
Table 1: Eighth Grade Attendance in German School Tracks in 2005/2006 (in Percentages)

\begin{tabular}{|c|c|c|c|}
\hline & \multicolumn{3}{|c|}{ West } \\
\hline & Germany & Germany & Hessen \\
\hline Lower secondary (Hauptschule) & 22 & 26 & 17 \\
\hline Intermediate secondary (Realschule) & 26 & 29 & 27 \\
\hline Higher secondary (Gymnasium) & 31 & 31 & 35 \\
\hline Comprehensive schools ${ }^{\mathrm{A}}$ (Gesamtschule) & 15 & 9 & 15 \\
\hline Special schools ${ }^{\mathrm{B}}$ (Sonderschule) & 1 & 1 & 1 \\
\hline Free Waldorf Schools (private) ${ }^{\mathrm{C}}$ & 5 & 5 & 5 \\
\hline
\end{tabular}

Note: ${ }^{A}$ Comprehensive schools include further combined school types. ${ }^{\mathrm{B}}$ For children with special needs, mostly due to physical or mental disabilities. ${ }^{C}$ Waldorf schools follow a special educational philosophy and may lead to different secondary diplomas.

Source: Federal Statistical Office (2006), Fachserie 11.1.

Table 2: Grade Levels for School Entry Cohorts

\begin{tabular}{lllllll}
\hline \hline & (entry year) & $2002 / 03$ & $2003 / 04$ & $2004 / 05$ & $2005 / 06$ & $2006 / 07$ \\
\hline Cohort 1 & $(1998)$ & 5 & 6 & 7 & 8 & 9 \\
Cohort 2 & $(1997)$ & 6 & 7 & 8 & 9 & 10 \\
Cohort 3 & $(1996)$ & 7 & 8 & 9 & 10 & 11 \\
Cohort 4 & $(1995)$ & 8 & 9 & 10 & 11 & 12 \\
Cohort 5 & $(1994)$ & 9 & 10 & 11 & 12 & 13 \\
Cohort 6 & $(1993)$ & 10 & 11 & 12 & 13 & --- \\
\hline \hline
\end{tabular}

Note: Grades refer to the supposed grade levels of students (if grades are not repeated or skipped) who entered school in the indicated year and are observed between 2002/03 and 2006/07.

Table 3: Grammar School Entry and Exit Rates

\begin{tabular}{lllllll}
\hline Entry rates & (entry year) & $2002 / 03$ & $2003 / 04$ & $2004 / 05$ & $2005 / 06$ & $2006 / 07$ \\
\hline Cohort 1 & $(1998)$ & --- & 0.09 & $\mathbf{0 . 1 6}$ & 0.02 & 0.01 \\
Cohort 2 & $(1997)$ & 0.13 & $\mathbf{0 . 2 2}$ & 0.02 & 0.01 & 0.01 \\
Cohort 3 & $(1996)$ & $\mathbf{0 . 1 8}$ & 0.04 & 0.01 & 0.01 & $\mathbf{0 . 4 5}$ \\
Cohort 4 & $(1995)$ & 0.03 & 0.01 & 0.01 & $\mathbf{0 . 4 4}$ & 0.17 \\
Cohort 5 & $(1994)$ & 0.01 & 0.02 & $\mathbf{0 . 4 4}$ & 0.17 & 0.08 \\
Cohort 6 & $(1993)$ & 0.01 & $\mathbf{0 . 4 5}$ & 0.17 & 0.08 & --- \\
\hline Exit rates & $($ entry year) & $2002 / 03$ & $2003 / 04$ & $2004 / 05$ & $2005 / 06$ & $2006 / 07$ \\
\hline Cohort 1 & $(1998)$ & --- & 0.02 & $\mathbf{0 . 0 2}$ & 0.02 & 0.03 \\
Cohort 2 & $(1997)$ & 0.04 & $\mathbf{0 . 0 2}$ & 0.02 & 0.03 & 0.03 \\
Cohort 3 & $(1996)$ & $\mathbf{0 . 0 3}$ & 0.02 & 0.03 & 0.03 & $\mathbf{0 . 0 2}$ \\
Cohort 4 & $(1995)$ & 0.04 & 0.03 & 0.03 & $\mathbf{0 . 0 3}$ & 0.03 \\
Cohort 5 & $(1994)$ & 0.05 & 0.04 & $\mathbf{0 . 0 3}$ & 0.03 & 0.03 \\
Cohort 6 & $(1993)$ & 0.05 & $\mathbf{0 . 0 3}$ & 0.03 & 0.03 & --- \\
\hline \hline
\end{tabular}

Note: The entry rates into (general or vocational) grammar school are so high between grades 10 and 11 because they also capture students from comprehensive schools who stay on to obtain the college entrance certificate (Abitur). Entry rates are defined as the ratio of students entering grammar school (from a lower track level) in a given grade related to the total number of students who had been in grammar school in the previous grade. Exit rates are defined as the number of students leaving the highest secondary track in a given grade divided by the total number of students in this track in the previous grade.

Source: Student-level data of the statistics on general and vocational schools for the state of Hessen 2002/03 to 2006/07 provided by the Hessen State Statistical Office (Hessisches Statistisches Landesamt). Authors' own calculations. 
Table 4: Correlations Between Instrument and Observables - Population of Students Born in June or July

\begin{tabular}{|c|c|c|c|c|c|}
\hline Variable & $2002 / 3$ & $2003 / 4$ & $2004 / 5$ & $2005 / 6$ & $2006 / 7$ \\
\hline \multicolumn{6}{|l|}{ Cohort 1: } \\
\hline Male & -0.01 & 0.00 & 0.00 & 0.00 & 0.00 \\
\hline Region: Darmstadt & 0.01 & 0.01 & 0.00 & 0.00 & 0.01 \\
\hline Region: Frankfurt & 0.00 & 0.00 & 0.00 & 0.00 & 0.00 \\
\hline Region: Offenbach, Offenbach-Land & 0.00 & 0.00 & 0.00 & 0.01 & 0.01 \\
\hline Region: Wiesbaden, Main-Taunus, Rheingau-Taunus. & 0.00 & 0.01 & 0.01 & 0.00 & 0.00 \\
\hline Region: Bergstraße, Odenwald, Dieburg, Groß-Gerau & 0.00 & 0.00 & 0.01 & 0.01 & 0.01 \\
\hline Region: Hochtaunus, Wetterau & 0.01 & 0.01 & 0.01 & 0.01 & 0.01 \\
\hline Region: Main-Kinzig & -0.01 & -0.01 & -0.01 & 0.00 & -0.01 \\
\hline Region: Gießen, Lahn-Dill, Limburg-Weilburg & -0.01 & -0.01 & -0.01 & -0.01 & -0.01 \\
\hline Region: Marburg-Biedenkopf, Vogelsberg & 0.01 & 0.01 & 0.00 & 0.00 & 0.00 \\
\hline Region: Kassel & -0.01 & -0.01 & 0.00 & -0.01 & 0.00 \\
\hline Region: Fulda, Hersfeld-Rotenburg & -0.01 & -0.01 & -0.01 & -0.01 & -0.01 \\
\hline Region: Kassel-Land, Werra-Meißner, Schwalm-Eder, Waldeck-F. & 0.00 & 0.00 & 0.00 & 0.00 & 0.00 \\
\hline Nationality: German speaking country & 0.01 & 0.01 & 0.01 & 0.01 & 0.01 \\
\hline Nationality: Turkey & -0.01 & -0.01 & -0.01 & -0.01 & $-0.02^{* *}$ \\
\hline Nationality: Italy, Greece & -0.01 & 0.00 & -0.01 & -0.01 & -0.01 \\
\hline Nationality: Former Yugoslavian states & -0.01 & -0.01 & 0.00 & 0.01 & 0.01 \\
\hline Nationality: Remaining Western countries & 0.00 & 0.00 & -0.01 & -0.01 & -0.01 \\
\hline Nationality: Eastern Europe, former Soviet Union & -0.01 & -0.01 & 0.00 & 0.00 & 0.00 \\
\hline Nationality: Remaining Muslim countries & 0.01 & 0.00 & 0.00 & 0.00 & 0.01 \\
\hline Nationality: Remaining Asia & 0.00 & 0.01 & 0.01 & 0.01 & 0.01 \\
\hline Nationality: Remaining countries & 0.00 & 0.00 & -0.01 & -0.01 & 0.00 \\
\hline \multicolumn{6}{|l|}{ Cohort 6: } \\
\hline Male & $-0.02^{*}$ & $-0.03^{\star *}$ & -0.01 & -0.02 & --- \\
\hline Region: Darmstadt & 0.01 & 0.00 & -0.01 & 0.00 & --- \\
\hline Region: Frankfurt & 0.01 & 0.01 & 0.00 & 0.00 & --- \\
\hline Region: Offenbach, Offenbach-Land & 0.00 & -0.01 & 0.01 & $0.02^{*}$ & --- \\
\hline Region: Wiesbaden, Main-Taunus, Rheingau-Taunus. & 0.01 & 0.00 & 0.00 & -0.01 & --- \\
\hline Region: Bergstraße, Odenwald, Dieburg, Groß-Gerau & 0.00 & 0.00 & -0.01 & 0.00 & --- \\
\hline Region: Hochtaunus, Wetterau & 0.01 & 0.01 & 0.00 & -0.01 & --- \\
\hline Region: Main-Kinzig & 0.00 & -0.01 & -0.01 & -0.01 & --- \\
\hline Region: Gießen, Lahn-Dill, Limburg-Weilburg & -0.02 & -0.01 & 0.00 & 0.00 & --- \\
\hline Region: Marburg-Biedenkopf, Vogelsberg & $0.02^{*}$ & 0.01 & 0.00 & 0.01 & --- \\
\hline Region: Kassel & $-0.03^{* *}$ & 0.00 & 0.01 & 0.01 & --- \\
\hline Region: Fulda, Hersfeld-Rotenburg & 0.00 & -0.01 & 0.01 & 0.00 & --- \\
\hline Region: Kassel-Land, Werra-Meißner, Schwalm-Eder, Waldeck-F. & 0.00 & 0.01 & 0.00 & -0.01 & --- \\
\hline Nationality: German speaking country & 0.02 & 0.01 & 0.01 & 0.02 & --- \\
\hline Nationality: Turkey & $-0.03^{* *}$ & $-0.02^{* *}$ & -0.02 & $-0.02^{* *}$ & --- \\
\hline Nationality: Italy, Greece & 0.00 & $0.02^{*}$ & 0.01 & 0.01 & --- \\
\hline Nationality: Former Yugoslavian states & 0.00 & 0.00 & -0.01 & -0.01 & --- \\
\hline Nationality: Remaining Western countries & 0.00 & 0.00 & 0.00 & 0.00 & --- \\
\hline Nationality: Eastern Europe, former Soviet Union & 0.00 & -0.01 & -0.01 & -0.02 & --- \\
\hline Nationality: Remaining Muslim countries & 0.00 & 0.00 & 0.00 & 0.01 & --- \\
\hline Nationality: Remaining Asia & 0.01 & $0.02^{*}$ & 0.01 & 0.01 & --- \\
\hline Nationality: Remaining countries & 0.00 & 0.01 & 0.01 & -0.01 & --- \\
\hline
\end{tabular}

Note: * ${ }^{*}$ ignificant at the 10 percent level. ${ }^{* *}$ Significant at the 5 percent level. Information on cohort 6 in 2006/07 is missing since these students would have to be in grade 14 (which does not exist).

Source: Student-level data of the statistics on general and vocational schools for the state of Hessen 2002/03 to 2006/07 provided by the Hessen State Statistical Office (Hessisches Statistisches Landesamt). Authors' own calculations. 
Table 5: First-Stage Results-Population of Students Born in June or July

\begin{tabular}{|c|c|c|c|c|c|c|}
\hline & & $2002 / 03$ & $2003 / 04$ & $2004 / 05$ & $2005 / 06$ & $2006 / 07$ \\
\hline \multirow{3}{*}{$\begin{array}{l}\text { Cohort } 1 \\
(1998)\end{array}$} & Coefficient & 0.40 ** & $0.42^{* *}$ & $0.42^{* *}$ & $0.41^{* *}$ & $0.41^{* *}$ \\
\hline & $(F)$ & (1222) & (1305) & (1217) & (1149) & (1120) \\
\hline & Observations & 11090 & 10790 & 10850 & 10835 & 10630 \\
\hline \multirow{3}{*}{$\begin{array}{l}\text { Cohort } 2 \\
\text { (1997) }\end{array}$} & Coefficient & $0.41^{* *}$ & $0.41^{* *}$ & $0.42^{* *}$ & $0.42^{* *}$ & $0.41^{* *}$ \\
\hline & $(F)$ & (1157) & (1082) & (1147) & (1113) & (1037) \\
\hline & Observations & 10335 & 10417 & 10480 & 10518 & 10192 \\
\hline \multirow{3}{*}{$\begin{array}{l}\text { Cohort } 3 \\
(1996)\end{array}$} & Coefficient & $0.33^{* *}$ & $0.33^{* *}$ & $0.33^{* *}$ & $0.33^{* *}$ & $0.31^{* *}$ \\
\hline & $(F)$ & (798) & $(780)$ & (692) & (667) & (597) \\
\hline & Observations & 10926 & 10947 & 11049 & 10905 & 10905 \\
\hline \multirow{3}{*}{$\begin{array}{l}\text { Cohort } 4 \\
(1995)\end{array}$} & Coefficient & $0.31^{* *}$ & $0.31^{* *}$ & $0.31^{* *}$ & $0.31^{* *}$ & $0.32^{* *}$ \\
\hline & $(F)$ & (693) & $(655)$ & $(672)$ & (651) & (626) \\
\hline & Observations & 11064 & 11078 & 10788 & 10788 & 10788 \\
\hline \multirow{3}{*}{$\begin{array}{l}\text { Cohort } 5 \\
(1994)\end{array}$} & Coefficient & $0.33^{* *}$ & $0.34^{* *}$ & $0.34^{* *}$ & $0.34^{* *}$ & $0.34^{* *}$ \\
\hline & $(F)$ & (849) & (820) & (771) & $(762)$ & $(685)$ \\
\hline & Observations & 10753 & 10400 & 10400 & 10400 & 10400 \\
\hline \multirow{4}{*}{$\begin{array}{l}\text { Cohort } 6 \\
(1993)\end{array}$} & Coefficient & $0.34^{* *}$ & $0.34^{* *}$ & $0.34^{* *}$ & $0.33^{* *}$ & --- \\
\hline & $(F)$ & (784) & (755) & $(724)$ & (685) & --- \\
\hline & Observations & 10253 & 10253 & 10253 & 10253 & --- \\
\hline & Results with & t lost obs & tions & & & \\
\hline \multirow{3}{*}{$\begin{array}{l}\text { Cohort } 3 \\
(1996)\end{array}$} & Coefficient & $0.33^{* *}$ & $0.33^{* *}$ & $0.33^{* *}$ & $0.33^{* *}$ & $0.30 * *$ \\
\hline & $(F)$ & (798) & $(780)$ & (692) & (667) & (499) \\
\hline & Observations & 10926 & 10947 & 11049 & 10905 & 9853 \\
\hline \multirow{3}{*}{$\begin{array}{l}\text { Cohort } 4 \\
(1995)\end{array}$} & Coefficient & $0.31^{* *}$ & $0.31^{* *}$ & $0.31^{* *}$ & $0.31^{* *}$ & $0.33^{* *}$ \\
\hline & $(F)$ & (693) & (655) & (672) & (557) & $(520)$ \\
\hline & Observations & 11064 & 11078 & 10788 & 10001 & 9345 \\
\hline \multirow{3}{*}{$\begin{array}{l}\text { Cohort } 5 \\
(1994)\end{array}$} & Coefficient & $0.33^{* *}$ & $0.34^{* *}$ & $0.33^{* *}$ & $0.33^{* *}$ & $0.33^{* *}$ \\
\hline & $(F)$ & (849) & (820) & (714) & $(560)$ & $(450)$ \\
\hline & Observations & 10753 & 10400 & 10054 & 8872 & 8086 \\
\hline \multirow{3}{*}{$\begin{array}{l}\text { Cohort } 6 \\
(1993)\end{array}$} & Coefficient & $0.34^{* *}$ & $0.34^{* *}$ & $0.35^{* *}$ & $0.33^{* *}$ & --- \\
\hline & $(F)$ & (784) & (658) & (624) & $(471)$ & --- \\
\hline & Observations & 10253 & 9464 & 8722 & 7812 & --- \\
\hline
\end{tabular}

Note: Ordinary least squares (OLS) regressions of school entry age on assigned school entry age. ${ }^{*}$ Significant at the 10 percent level. ${ }^{*}$ Significant at the 5 percent level. Documented coefficients refer to specifications without control variables. Effects are robust if available control variables (gender, region, and nationality) are considered. The upper panel of the estimates includes simulation results holding the number of observations constant for grades 10 to 13 (see Section 3.3). Missing observations are assumed to be lower track students since they would be in the data if they had sought a higher secondary diploma. The lower panel of the estimates shows the results based only on observed students without simulated observations.

Source: Student-level data of the statistics on general and vocational schools for the state of Hessen 2002/03 to 2006/07 provided by the Hessen State Statistical Office (Hessisches Statistisches Landesamt). Authors' own calculations. 
Table 6: OLS Results-Population of Students Born in June or July

\begin{tabular}{|c|c|c|c|c|c|c|}
\hline & & $2002 / 03$ & $2003 / 04$ & $2004 / 05$ & $2005 / 06$ & $2006 / 07$ \\
\hline Cohort 1 & Coefficient & $-0.02^{* *}$ & $-0.09^{* *}$ & $-0.11^{* *}$ & $-0.12^{\star *}$ & $-0.12^{* *}$ \\
\hline \multirow[t]{2}{*}{ (1998) } & (s.e.) & $(0.01)$ & $(0.01)$ & $(0.01)$ & $(0.01)$ & $(0.01)$ \\
\hline & Observations & 11090 & 10790 & 10850 & 10835 & 10630 \\
\hline \multirow{3}{*}{$\begin{array}{l}\text { Cohort } 2 \\
(1997)\end{array}$} & Coefficient & $-0.11^{* *}$ & $-0.12^{\star *}$ & $-0.12^{\star *}$ & $-0.13^{\star *}$ & $-0.12^{\star *}$ \\
\hline & (s.e.) & $(0.01)$ & $(0.01)$ & $(0.01)$ & $(0.01)$ & $(0.01)$ \\
\hline & Observations & 10335 & 10417 & 10480 & 10518 & 10192 \\
\hline \multirow{3}{*}{$\begin{array}{l}\text { Cohort } 3 \\
\text { (1996) }\end{array}$} & Coefficient & $-0.09^{* *}$ & $-0.11^{* *}$ & $-0.11^{* *}$ & $-0.11^{* *}$ & $-0.04^{* *}$ \\
\hline & (s.e.) & $(0.01)$ & $(0.01)$ & $(0.01)$ & $(0.01)$ & $(0.01)$ \\
\hline & Observations & 10926 & 10947 & 11049 & 10905 & 10905 \\
\hline \multirow{3}{*}{$\begin{array}{l}\text { Cohort } 4 \\
(1995)\end{array}$} & Coefficient & $-0.11^{\star *}$ & $-0.11^{* *}$ & $-0.11^{* *}$ & $-0.04^{* *}$ & $-0.04^{* *}$ \\
\hline & (s.e.) & $(0.01)$ & $(0.01)$ & $(0.01)$ & $(0.01)$ & $(0.01)$ \\
\hline & Observations & 11064 & 11078 & 10788 & 10788 & 10788 \\
\hline \multirow{3}{*}{$\begin{array}{l}\text { Cohort } 5 \\
(1994)\end{array}$} & Coefficient & $-0.10^{* *}$ & $-0.08^{* *}$ & 0.00 & $-0.04^{* *}$ & $-0.09^{* *}$ \\
\hline & (s.e.) & $(0.01)$ & $(0.01)$ & $(0.01)$ & $(0.01)$ & $(0.01)$ \\
\hline & Observations & 10753 & 10400 & 10400 & 10400 & 10400 \\
\hline \multirow{3}{*}{$\begin{array}{l}\text { Cohort } 6 \\
(1993)\end{array}$} & Coefficient & $-0.08^{* *}$ & $-0.02^{* *}$ & $-0.04^{* *}$ & $-0.07^{* *}$ & --- \\
\hline & (s.e.) & $(0.01)$ & $(0.01)$ & $(0.01)$ & $(0.01)$ & --- \\
\hline & Observations & 10253 & 10253 & 10253 & 10253 & --- \\
\hline & Results with & it lost ob & ations & & & \\
\hline \multirow{3}{*}{$\begin{array}{l}\text { Cohort } 3 \\
\text { (1996) }\end{array}$} & Coefficient & $-0.09^{* *}$ & $-0.11^{* *}$ & $-0.11^{* *}$ & $-0.11^{* *}$ & -0.01 \\
\hline & (s.e.) & $(0.01)$ & $(0.01)$ & $(0.01)$ & $(0.01)$ & $(0.01)$ \\
\hline & Observations & 10926 & 10947 & 11049 & 10905 & 9853 \\
\hline \multirow{3}{*}{$\begin{array}{l}\text { Cohort } 4 \\
(1995)\end{array}$} & Coefficient & $-0.11^{* *}$ & $-0.11^{* *}$ & $-0.11^{* *}$ & $-0.02^{* *}$ & 0.01 \\
\hline & (s.e.) & $(0.01)$ & $(0.01)$ & $(0.01)$ & $(0.01)$ & $(0.01)$ \\
\hline & Observations & 11064 & 11078 & 10788 & 10001 & 9345 \\
\hline \multirow{3}{*}{$\begin{array}{l}\text { Cohort } 5 \\
(1994)\end{array}$} & Coefficient & $-0.10^{* *}$ & $-0.08^{* *}$ & 0.01 & $0.02^{* *}$ & $-0.01^{*}$ \\
\hline & (s.e.) & $(0.01)$ & $(0.01)$ & $(0.01)$ & $(0.01)$ & $(0.01)$ \\
\hline & Observations & 10753 & 10400 & 10054 & 8872 & 8086 \\
\hline \multirow{3}{*}{$\begin{array}{l}\text { Cohort } 6 \\
(1993)\end{array}$} & Coefficient & $-0.08^{* *}$ & 0.00 & $0.04^{* *}$ & $0.02^{*}$ & --- \\
\hline & (s.e.) & $(0.01)$ & (0.01) & $(0.01)$ & $(0.01)$ & --- \\
\hline & Observations & 10253 & 9464 & 8722 & 7812 & --- \\
\hline
\end{tabular}

Note: OLS regressions of a binary indicator for attending grammar school on school entry age. *Significant at the10 percent level. **Significant at the 5 percent level. Documented coefficients refer to specifications without control variables. Effects are robust if available control variables (gender, region, and nationality) are considered. The upper panel of the estimates includes simulation results holding the number of observations constant for grades 10 to 13 (see Section 3.3). Missing observations are assumed to be lower track students since they would be in the data if they had sought a higher secondary diploma. The lower panel of the estimates shows the results based only on observed students without simulated observations.

Source: Student-level data of the statistics on general and vocational schools for the state of Hessen 2002/03 to 2006/07 provided by the Hessen State Statistical Office (Hessisches Statistisches Landesamt). Authors' own calculations. 
Table 7: Second-Stage Results—Population of Students Born in June or July

\begin{tabular}{|c|c|c|c|c|c|c|}
\hline & & $2002 / 03$ & $2003 / 04$ & $2004 / 05$ & $2005 / 06$ & $2006 / 07$ \\
\hline Cohort 1 & Coefficient & $0.13^{* *}$ & $0.15^{* *}$ & $0.16^{* *}$ & $0.12^{* *}$ & $0.11^{* *}$ \\
\hline \multirow{2}{*}{ (1998) } & (s.e.) & $(0.02)$ & $(0.02)$ & $(0.03)$ & $(0.03)$ & $(0.03)$ \\
\hline & Observations & 11090 & 10790 & 10850 & 10835 & 10630 \\
\hline \multirow{3}{*}{$\begin{array}{l}\text { Cohort } 2 \\
\text { (1997) }\end{array}$} & Coefficient & $0.09^{* *}$ & $0.10^{* *}$ & $0.08^{* *}$ & $0.08^{* *}$ & $0.08^{* *}$ \\
\hline & (s.e.) & $(0.02)$ & $(0.03)$ & $(0.02)$ & $(0.02)$ & $(0.03)$ \\
\hline & Observations & 10335 & 10417 & 10480 & 10518 & 10192 \\
\hline \multirow{3}{*}{$\begin{array}{l}\text { Cohort } 3 \\
\text { (1996) }\end{array}$} & Coefficient & $0.13^{* *}$ & $0.13^{* *}$ & $0.12^{* *}$ & $0.14^{* *}$ & 0.05 \\
\hline & (s.e.) & $(0.03)$ & $(0.03)$ & $(0.03)$ & $(0.03)$ & $(0.03)$ \\
\hline & Observations & 10926 & 10947 & 11049 & 10905 & 10905 \\
\hline \multirow{3}{*}{$\begin{array}{l}\text { Cohort } 4 \\
\text { (1995) }\end{array}$} & Coefficient & $0.19^{* *}$ & $0.15^{* *}$ & $0.14^{* *}$ & $0.07^{* *}$ & 0.05 \\
\hline & (s.e.) & $(0.03)$ & $(0.03)$ & $(0.03)$ & $(0.03)$ & $(0.03)$ \\
\hline & Observations & 11064 & 11078 & 10788 & 10788 & 10788 \\
\hline \multirow{3}{*}{$\begin{array}{l}\text { Cohort } 5 \\
\text { (1994) }\end{array}$} & Coefficient & $0.14^{* *}$ & $0.14^{* *}$ & $0.09^{* *}$ & 0.03 & 0.00 \\
\hline & (s.e.) & $(0.03)$ & $(0.03)$ & $(0.03)$ & $(0.03)$ & $(0.03)$ \\
\hline & Observations & 10753 & 10400 & 10400 & 10400 & 10400 \\
\hline \multirow{3}{*}{$\begin{array}{l}\text { Cohort } 6 \\
(1993)\end{array}$} & Coefficient & $0.16^{* *}$ & 0.03 & 0.00 & 0.02 & --- \\
\hline & (s.e.) & $(0.03)$ & $(0.03)$ & $(0.03)$ & $(0.03)$ & --- \\
\hline & Observations & 10253 & 10253 & 10253 & 10253 & --- \\
\hline & \multicolumn{6}{|c|}{ Results without lost observations } \\
\hline \multirow{3}{*}{$\begin{array}{l}\text { Cohort } 3 \\
\text { (1996) }\end{array}$} & Coefficient & $0.13^{* *}$ & $0.13^{* *}$ & $0.12^{* *}$ & $0.14^{* *}$ & $0.11^{* *}$ \\
\hline & (s.e.) & $(0.03)$ & $(0.03)$ & $(0.03)$ & $(0.03)$ & $(0.04)$ \\
\hline & Observations & 10926 & 10947 & 11049 & 10905 & 9853 \\
\hline \multirow{3}{*}{$\begin{array}{l}\text { Cohort } 4 \\
\text { (1995) }\end{array}$} & Coefficient & $0.19^{* *}$ & $0.15^{* *}$ & $0.14^{* *}$ & $0.10^{* *}$ & $0.08^{* *}$ \\
\hline & (s.e.) & $(0.03)$ & $(0.03)$ & $(0.03)$ & $(0.04)$ & $(0.03)$ \\
\hline & Observations & 11064 & 11078 & 10788 & 10001 & 9345 \\
\hline \multirow{3}{*}{$\begin{array}{l}\text { Cohort } 5 \\
(1994)\end{array}$} & Coefficient & $0.14^{* *}$ & $0.14^{* *}$ & $0.11^{* *}$ & $0.09^{* *}$ & 0.05 \\
\hline & (s.e.) & $(0.03)$ & $(0.03)$ & $(0.03)$ & $(0.04)$ & $(0.04)$ \\
\hline & Observations & 10753 & 10400 & 10054 & 8872 & 8086 \\
\hline \multirow{3}{*}{$\begin{array}{l}\text { Cohort } 6 \\
(1993)\end{array}$} & Coefficient & $0.16^{* *}$ & 0.05 & $0.09^{* *}$ & 0.04 & --- \\
\hline & (s.e.) & $(0.03)$ & $(0.03)$ & $(0.03)$ & $(0.04)$ & --- \\
\hline & Observations & 10253 & 9464 & 8722 & 7812 & --- \\
\hline
\end{tabular}

Note: Two-stage least squares regressions of a binary indicator for attending grammar school on school entry age, instrumented by assigned school entry age. *Significant at the 10 percent level. ${ }^{* *}$ Significant at the 5 percent level. Documented coefficients refer to specifications without control variables. Effects are robust if available control variables (gender, region, and nationality) are considered. The upper panel of the estimates includes simulation results holding the number of observations constant for grades 10 to 13 (see Section 3.3). Missing observations are assumed to be lower track students since they would be in the data if they had sought a higher secondary diploma. The lower panel of the estimates shows the results based only on observed students without simulated observations.

Source: Student-level data of the statistics on general and vocational schools for the state of Hessen 2002/03 to 2006/07 provided by the Hessen State Statistical Office (Hessisches Statistisches Landesamt). Authors' own calculations. 
Table 8: Second-Stage Results for a Change-to-Grammar-School Outcome-Population of Students Born in June or July

\begin{tabular}{|c|c|c|c|c|c|c|}
\hline & & $2002 / 03$ & $2003 / 04$ & $2004 / 05$ & $2005 / 06$ & $2006 / 07$ \\
\hline $\begin{array}{l}\text { Cohort } 1 \\
\text { (1998) }\end{array}$ & $\begin{array}{l}\text { Coefficient } \\
\text { (s.e.) } \\
\text { Observations }\end{array}$ & $\begin{array}{l}0.13^{* *} \\
(0.02) \\
11077\end{array}$ & $\begin{array}{l}0.01 \\
(0.01) \\
10780\end{array}$ & $\begin{array}{l}0.02 \\
(0.01) \\
10842\end{array}$ & $\begin{array}{l}-0.01^{\star *} \\
(0.00) \\
10824\end{array}$ & $\begin{array}{l}0.00 \\
(0.00) \\
10630\end{array}$ \\
\hline $\begin{array}{l}\text { Cohort } 2 \\
\text { (1997) }\end{array}$ & $\begin{array}{l}\text { Coefficient } \\
\text { (s.e.) } \\
\text { Observations }\end{array}$ & $\begin{array}{l}0.02^{* *} \\
(0.01) \\
10318\end{array}$ & $\begin{array}{l}0.00 \\
(0.01) \\
10412\end{array}$ & $\begin{array}{l}0.00 \\
(0.00) \\
10476\end{array}$ & $\begin{array}{l}0.00 \\
(0.00) \\
10512\end{array}$ & $\begin{array}{l}0.00 \\
(0.00) \\
10192\end{array}$ \\
\hline $\begin{array}{l}\text { Cohort } 3 \\
\text { (1996) }\end{array}$ & $\begin{array}{l}\text { Coefficient } \\
\text { (s.e.) } \\
\text { Observations }\end{array}$ & $\begin{array}{l}0.00 \\
(0.01) \\
10923\end{array}$ & $\begin{array}{l}0.02^{* *} \\
(0.01) \\
10934\end{array}$ & $\begin{array}{l}0.00 \\
(0.00) \\
11044\end{array}$ & $\begin{array}{l}0.01 \\
(0.00) \\
10902\end{array}$ & $\begin{array}{l}-0.08^{* *} \\
(0.02) \\
10902\end{array}$ \\
\hline $\begin{array}{l}\text { Cohort } 4 \\
\text { (1995) }\end{array}$ & $\begin{array}{l}\text { Coefficient } \\
\text { (s.e.) } \\
\text { Observations }\end{array}$ & $\begin{array}{l}0.01^{*} \\
(0.01) \\
11061\end{array}$ & $\begin{array}{l}-0.01^{\star *} \\
(0.00) \\
11069\end{array}$ & $\begin{array}{l}-0.01^{*} \\
(0.00) \\
10787\end{array}$ & $\begin{array}{l}-0.04 \\
(0.02) \\
10787\end{array}$ & $\begin{array}{l}-0.03^{*} \\
(0.02) \\
10787\end{array}$ \\
\hline $\begin{array}{l}\text { Cohort } 5 \\
\text { (1994) }\end{array}$ & $\begin{array}{l}\text { Coefficient } \\
\text { (s.e.) } \\
\text { Observations }\end{array}$ & $\begin{array}{l}0.00 \\
(0.00) \\
10744\end{array}$ & $\begin{array}{l}0.01^{*} \\
(0.00) \\
10396\end{array}$ & $\begin{array}{l}-0.05^{\star *} \\
(0.02) \\
10396\end{array}$ & $\begin{array}{l}-0.03^{*} \\
(0.02) \\
10396\end{array}$ & $\begin{array}{l}-0.02^{*} \\
(0.01) \\
10396\end{array}$ \\
\hline $\begin{array}{l}\text { Cohort } 6 \\
\text { (1993) }\end{array}$ & $\begin{array}{l}\text { Coefficient } \\
\text { (s.e.) } \\
\text { Observations }\end{array}$ & $\begin{array}{l}0.00 \\
(0.00) \\
10248\end{array}$ & $\begin{array}{l}-0.06^{\star *} \\
(0.02) \\
10248\end{array}$ & $\begin{array}{l}0.00 \\
(0.02) \\
10248\end{array}$ & $\begin{array}{l}0.01 \\
(0.01) \\
10248\end{array}$ & --- \\
\hline & Results withc & t lost obs & ations & & & \\
\hline $\begin{array}{l}\text { Cohort } 3 \\
\text { (1996) }\end{array}$ & $\begin{array}{l}\text { Coefficient } \\
\text { (s.e.) } \\
\text { Observations }\end{array}$ & $\begin{array}{l}0.00 \\
(0.01) \\
10923\end{array}$ & $\begin{array}{l}0.02^{* *} \\
(0.01) \\
10934\end{array}$ & $\begin{array}{l}0.00 \\
(0.00) \\
11044\end{array}$ & $\begin{array}{l}0.01 \\
(0.00) \\
10902\end{array}$ & $\begin{array}{l}-0.08^{* \star} \\
(0.03) \\
9853\end{array}$ \\
\hline $\begin{array}{l}\text { Cohort } 4 \\
\text { (1995) }\end{array}$ & $\begin{array}{l}\text { Coefficient } \\
\text { (s.e.) } \\
\text { Observations }\end{array}$ & $\begin{array}{l}0.01^{*} \\
(0.01) \\
11061\end{array}$ & $\begin{array}{l}-0.01^{* *} \\
(0.00) \\
11069\end{array}$ & $\begin{array}{l}-0.01^{*} \\
(0.00) \\
10787\end{array}$ & $\begin{array}{l}-0.04 \\
(0.03) \\
10001\end{array}$ & $\begin{array}{l}-0.02 \\
(0.02) \\
9345\end{array}$ \\
\hline $\begin{array}{l}\text { Cohort } 5 \\
\text { (1994) }\end{array}$ & $\begin{array}{l}\text { Coefficient } \\
\text { (s.e.) } \\
\text { Observations }\end{array}$ & $\begin{array}{l}0.00 \\
(0.00) \\
10744\end{array}$ & $\begin{array}{l}0.01^{*} \\
(0.00) \\
10396\end{array}$ & $\begin{array}{l}-0.04^{*} \\
(0.02) \\
10053\end{array}$ & $\begin{array}{l}-0.03 \\
(0.02) \\
8871\end{array}$ & $\begin{array}{l}-0.02 \\
(0.02) \\
8086\end{array}$ \\
\hline $\begin{array}{l}\text { Cohort } 6 \\
\text { (1993) }\end{array}$ & $\begin{array}{l}\text { Coefficient } \\
\text { (s.e.) } \\
\text { Observations }\end{array}$ & $\begin{array}{l}0.00 \\
(0.00) \\
10248\end{array}$ & $\begin{array}{l}-0.06^{* *} \\
(0.02) \\
9463\end{array}$ & $\begin{array}{l}0.02 \\
(0.02) \\
8722\end{array}$ & $\begin{array}{l}0.01 \\
(0.02) \\
7812\end{array}$ & $\begin{array}{l}--- \\
--- \\
---\end{array}$ \\
\hline
\end{tabular}

Note: Two-stage least squares regressions of a binary indicator for upgrading to grammar school on school entry age, instrumented by assigned school entry age. Grammar school students are included in the regressions, although they cannot upgrade, to make the coefficients comparable with changes in coefficients of regressions with attending grammar school as the outcome variable. ${ }^{*}$ Significant at the 10 percent level. ${ }^{*}$ Significant at the 5 percent level. Documented coefficients refer to specifications without control variables. Effects are robust if available control variables (gender, region, and nationality) are considered. The upper panel of the estimates includes simulation results holding the number of observations constant for grades 10 to 13 (see Section 3.3). Missing observations are assumed to be lower track students since they would be in the data if they had sought a higher secondary diploma. The lower panel of the estimates shows the results based only on observed students without simulated observations.

Source: Student-level data of the statistics on general and vocational schools for the state of Hessen 2002/03 to 2006/07 provided by the Hessen State Statistical Office (Hessisches Statistisches Landesamt). Authors' own calculations. 
Table 9: Second-Stage Results for a Grammar School Outcome—Population of Students Born in June or July ${ }^{\dagger}$

\begin{tabular}{|c|c|c|c|c|c|}
\hline & & $2003 / 04$ & $2004 / 05$ & $2005 / 06$ & $2006 / 07$ \\
\hline \multirow[t]{3}{*}{ Cohort 1} & Coefficient & $0.15^{\star *}$ & $0.14^{* *}$ & $0.12^{* *}$ & $0.16^{* *}$ \\
\hline & (s.e.) & $(0.03)$ & $(0.03)$ & $(0.03)$ & $(0.03)$ \\
\hline & Observations & 11217 & 11513 & 11580 & 11022 \\
\hline \multirow[t]{3}{*}{ Cohort 2} & Coefficient & $0.15^{* *}$ & $0.12^{* *}$ & $0.12^{* *}$ & $0.10^{* *}$ \\
\hline & (s.e.) & $(0.03)$ & $(0.03)$ & $(0.03)$ & $(0.03)$ \\
\hline & Observations & 11790 & 11832 & 11641 & 11215 \\
\hline \multirow[t]{3}{*}{ Cohort 3} & Coefficient & $0.12^{* *}$ & $0.13^{* *}$ & $0.13^{* *}$ & 0.04 \\
\hline & (s.e.) & $(0.03)$ & $(0.03)$ & $(0.03)$ & $(0.03)$ \\
\hline & Observations & 11565 & 11388 & 12098 & 13575 \\
\hline \multirow[t]{3}{*}{ Cohort 4} & Coefficient & $0.13^{* *}$ & $0.11^{* *}$ & 0.05 & 0.02 \\
\hline & (s.e.) & $(0.03)$ & $(0.03)$ & $(0.03)$ & $(0.03)$ \\
\hline & Observations & 11136 & 12156 & 13564 & 13564 \\
\hline \multirow[t]{3}{*}{ Cohort 5} & Coefficient & $0.12^{* *}$ & 0.03 & 0.02 & 0.03 \\
\hline & (s.e.) & $(0.03)$ & $(0.03)$ & $(0.03)$ & $(0.03)$ \\
\hline & Observations & 11772 & 12909 & 12909 & 12909 \\
\hline \multirow[t]{3}{*}{ Cohort 6} & Coefficient & --- & --- & --- & --- \\
\hline & (s.e.) & --- & --- & --- & --- \\
\hline & Observations & --- & --- & --- & --- \\
\hline & Results witho & t lost obs & ons & & \\
\hline \multirow[t]{3}{*}{ Cohort 3} & Coefficient & $0.12^{* *}$ & $0.13^{* *}$ & $0.13^{* *}$ & $0.11^{* *}$ \\
\hline & (s.e.) & $(0.03)$ & $(0.03)$ & $(0.03)$ & (0.03) \\
\hline & Observations & 11565 & 11388 & 12098 & 12230 \\
\hline \multirow[t]{3}{*}{ Cohort 4} & Coefficient & $0.13^{* *}$ & $0.11^{* *}$ & 0.04 & 0.04 \\
\hline & (s.e.) & $(0.03)$ & $(0.03)$ & $(0.03)$ & $(0.03)$ \\
\hline & Observations & 11136 & 12156 & 12481 & 12604 \\
\hline \multirow[t]{3}{*}{ Cohort 5} & Coefficient & $0.12^{* *}$ & $0.06^{*}$ & 0.05 & 0.03 \\
\hline & (s.e.) & $(0.03)$ & (0.03) & $(0.03)$ & $(0.03)$ \\
\hline & Observations & 11772 & 12187 & 10043 & 10496 \\
\hline \multirow[t]{3}{*}{ Cohort 6} & Coefficient & 0.05 & 0.02 & 0.03 & --- \\
\hline & (s.e.) & $(0.03)$ & $(0.03)$ & $(0.04)$ & --- \\
\hline & Observations & 11636 & 10241 & 7769 & --- \\
\hline
\end{tabular}

Note: ${ }^{\dagger}$ Students sorted by grade attended. Two-stage least squares regressions of a binary indicator for attending grammar school on school entry age, instrumented by assigned school entry age. *Significant at the 10 percent level. ${ }^{*}$ Significant at the 5 percent level. Documented coefficients refer to specifications without control variables. Effects are robust if available control variables (gender, region, and nationality) are considered. The upper panel of the estimates includes simulation results holding the number of observations constant for grades 11 to 13 (see Section 3.3). The number of observations rise between grade 10 and 11 in the original data probably due to wrong information on the actual grade (which is why we do not use the grade information for the results presented in the remaining parts of this study). Missing observations are assumed to be lower track students, since they would be in the data if they had sought a higher secondary diploma. The lower panel of the estimates shows the results based only on observed students without simulated observations. No simulations are available for cohort 6 since data are not available for the required reference group of tenth graders in 2002/03. Source: Student-level data of the statistics on general and vocational schools for the state of Hessen 2003/04 to 2006/07 provided by the Hessen State Statistical Office (Hessisches Statistisches Landesamt). Authors' own calculations. 
Table 10: Second-Stage Results for Very Narrow Definition of Grammar School Attendance-Population of Students Born in June or July

\begin{tabular}{|c|c|c|c|c|c|c|}
\hline & & $2002 / 03$ & $2003 / 04$ & $2004 / 05$ & $2005 / 06$ & 2006/2007 \\
\hline \multirow{3}{*}{$\begin{array}{l}\text { Cohort } 1 \\
\text { (1998) }\end{array}$} & Coefficient & $0.13^{* *}$ & $0.15^{* \star}$ & $0.16^{* *}$ & $0.12^{* *}$ & $0.11^{* *}$ \\
\hline & (s.e.) & $(0.02)$ & $(0.02)$ & $(0.03)$ & $(0.03)$ & $(0.03)$ \\
\hline & Observations & 11090 & 10790 & 10850 & 10835 & 10630 \\
\hline \multirow{3}{*}{$\begin{array}{l}\text { Cohort } 2 \\
\text { (1997) }\end{array}$} & Coefficient & $0.09^{* *}$ & $0.10^{* *}$ & $0.08^{* *}$ & $0.08^{* *}$ & $0.08^{* *}$ \\
\hline & (s.e.) & $(0.02)$ & $(0.03)$ & $(0.02)$ & $(0.02)$ & $(0.03)$ \\
\hline & Observations & 10335 & 10417 & 10480 & 10518 & 10192 \\
\hline \multirow{3}{*}{$\begin{array}{l}\text { Cohort } 3 \\
\text { (1996) }\end{array}$} & Coefficient & $0.13^{* *}$ & $0.13^{* *}$ & $0.12^{* *}$ & $0.14^{* *}$ & $0.11^{* *}$ \\
\hline & (s.e.) & $(0.03)$ & $(0.03)$ & $(0.03)$ & $(0.03)$ & $(0.03)$ \\
\hline & Observations & 10926 & 10947 & 11049 & 10905 & 10905 \\
\hline \multirow{3}{*}{$\begin{array}{l}\text { Cohort } 4 \\
\text { (1995) }\end{array}$} & Coefficient & $0.19^{* *}$ & $0.15^{* *}$ & $0.14^{* *}$ & $0.09^{* *}$ & $0.08^{* *}$ \\
\hline & (s.e.) & $(0.03)$ & $(0.03)$ & $(0.03)$ & $(0.03)$ & $(0.03)$ \\
\hline & Observations & 11064 & 11078 & 10788 & 10788 & 10788 \\
\hline \multirow{3}{*}{$\begin{array}{l}\text { Cohort } 5 \\
\text { (1994) }\end{array}$} & Coefficient & $0.14^{* *}$ & $0.13^{* *}$ & $0.11^{* *}$ & $0.08^{* *}$ & $0.07^{* *}$ \\
\hline & (s.e.) & $(0.03)$ & $(0.03)$ & (0.03) & $(0.03)$ & $(0.03)$ \\
\hline & Observations & 10753 & 10400 & 10400 & 10400 & 10400 \\
\hline \multirow{3}{*}{$\begin{array}{l}\text { Cohort } 6 \\
\text { (1993) }\end{array}$} & Coefficient & $0.16^{* *}$ & $0.09^{* *}$ & $0.06^{* *}$ & $0.08^{* *}$ & --- \\
\hline & (s.e.) & $(0.03)$ & $(0.03)$ & $(0.03)$ & $(0.03)$ & --- \\
\hline & Observations & 10253 & 10253 & 10253 & 10253 & --- \\
\hline & \multicolumn{6}{|c|}{ Results without lost observations } \\
\hline \multirow{3}{*}{$\begin{array}{l}\text { Cohort } 3 \\
\text { (1996) }\end{array}$} & Coefficient & $0.13^{* *}$ & $0.13^{* *}$ & $0.12^{* \star}$ & $0.14^{\star *}$ & $0.16^{\star *}$ \\
\hline & (s.e.) & $(0.03)$ & $(0.03)$ & $(0.03)$ & $(0.03)$ & $(0.04)$ \\
\hline & Observations & 10926 & 10947 & 11049 & 10905 & 9853 \\
\hline \multirow{3}{*}{$\begin{array}{l}\text { Cohort } 4 \\
\text { (1995) }\end{array}$} & Coefficient & $0.19^{* *}$ & $0.15^{* *}$ & $0.14^{* *}$ & $0.11^{* *}$ & $0.11^{* *}$ \\
\hline & (s.e.) & $(0.03)$ & $(0.03)$ & $(0.03)$ & $(0.04)$ & $(0.03)$ \\
\hline & Observations & 11064 & 11078 & 10788 & 10001 & 9345 \\
\hline \multirow{3}{*}{$\begin{array}{l}\text { Cohort } 5 \\
\text { (1994) }\end{array}$} & Coefficient & $0.14^{* *}$ & $0.13^{* *}$ & $0.13^{* *}$ & $0.13^{* *}$ & $0.13^{* *}$ \\
\hline & (s.e.) & $(0.03)$ & $(0.03)$ & $(0.03)$ & $(0.04)$ & $(0.04)$ \\
\hline & Observations & 10753 & 10400 & 10054 & 8872 & 8086 \\
\hline \multirow{3}{*}{$\begin{array}{l}\text { Cohort } 6 \\
\text { (1993) }\end{array}$} & Coefficient & $0.16^{* *}$ & $0.12^{* *}$ & $0.13^{\star *}$ & $0.11^{\star *}$ & --- \\
\hline & (s.e.) & $(0.03)$ & $(0.03)$ & $(0.03)$ & $(0.04)$ & --- \\
\hline & Observations & 10253 & 9464 & 8722 & 7812 & --- \\
\hline
\end{tabular}

Note: Two-stage least squares regressions of a binary indicator for attending the general (traditional) grammar school on school entry age, instrumented by assigned school entry age. *Significant at the 10 percent level. ${ }^{* *}$ Significant at the five percent level. Documented coefficients refer to specifications without control variables. Effects are robust if available control variables (gender, region and nationality) are considered. The upper panel of the estimates includes simulation results holding the number of observations constant for grades 10 to 13 (see Section 3.3). Missing observations are assumed to be lower track students since they would be in the data if they had sought a higher secondary diploma. The lower panel of the estimates shows the results based only on observed students without simulated observations.

Source: Student-level data of the statistics on general and vocational schools for the state of Hessen 2002/03 to 2006/07 provided by the Hessen State Statistical Office (Hessisches Statistisches Landesamt). Authors' own calculations. 
Table 11: Second-Stage Results for Narrow Definition of Grammar School Attendance-Population of Students Born in June or July

\begin{tabular}{|c|c|c|c|c|c|c|}
\hline & & $2002 / 03$ & $2003 / 04$ & $2004 / 05$ & $2005 / 06$ & $2006 / 2007$ \\
\hline $\begin{array}{l}\text { Cohort } 1 \\
\text { (1998) }\end{array}$ & $\begin{array}{l}\text { Coefficient } \\
\text { (s.e.) } \\
\text { Observations }\end{array}$ & $\begin{array}{l}0.13^{* *} \\
(0.02) \\
11090\end{array}$ & $\begin{array}{l}0.15^{\star *} \\
(0.02) \\
10790\end{array}$ & $\begin{array}{l}0.16^{* *} \\
(0.03) \\
10850\end{array}$ & $\begin{array}{l}0.12^{* *} \\
(0.03) \\
10835\end{array}$ & $\begin{array}{l}0.11^{* *} \\
(0.03) \\
10630\end{array}$ \\
\hline $\begin{array}{l}\text { Cohort } 2 \\
\text { (1997) }\end{array}$ & $\begin{array}{l}\text { Coefficient } \\
\text { (s.e.) } \\
\text { Observations }\end{array}$ & $\begin{array}{l}0.09^{* *} \\
(0.02) \\
10335\end{array}$ & $\begin{array}{l}0.10^{* *} \\
(0.03) \\
10417\end{array}$ & $\begin{array}{l}0.08^{* *} \\
(0.02) \\
10480\end{array}$ & $\begin{array}{l}0.08^{\star *} \\
(0.02) \\
10518\end{array}$ & $\begin{array}{l}0.08^{* *} \\
(0.03) \\
10192\end{array}$ \\
\hline $\begin{array}{l}\text { Cohort } 3 \\
\text { (1996) }\end{array}$ & $\begin{array}{l}\text { Coefficient } \\
\text { (s.e.) } \\
\text { Observations }\end{array}$ & $\begin{array}{l}0.13^{\star *} \\
(0.03) \\
10926\end{array}$ & $\begin{array}{l}0.13^{\star *} \\
(0.03) \\
10947\end{array}$ & $\begin{array}{l}0.12^{* *} \\
(0.03) \\
11049\end{array}$ & $\begin{array}{l}0.14^{* *} \\
(0.03) \\
10905\end{array}$ & $\begin{array}{l}0.10^{* *} \\
(0.03) \\
10905\end{array}$ \\
\hline $\begin{array}{l}\text { Cohort } 4 \\
\text { (1995) }\end{array}$ & $\begin{array}{l}\text { Coefficient } \\
\text { (s.e.) } \\
\text { Observations }\end{array}$ & $\begin{array}{l}0.19^{\star *} \\
(0.03) \\
11064\end{array}$ & $\begin{array}{l}0.15^{\star *} \\
(0.03) \\
11078\end{array}$ & $\begin{array}{l}0.14^{* *} \\
(0.03) \\
10788\end{array}$ & $\begin{array}{l}0.07^{* *} \\
(0.03) \\
10788\end{array}$ & $\begin{array}{l}0.06^{* *} \\
(0.03) \\
10788\end{array}$ \\
\hline $\begin{array}{l}\text { Cohort } 5 \\
(1994)\end{array}$ & $\begin{array}{l}\text { Coefficient } \\
\text { (s.e.) } \\
\text { Observations }\end{array}$ & $\begin{array}{l}0.14^{\star *} \\
(0.03) \\
10753\end{array}$ & $\begin{array}{l}0.13^{* *} \\
(0.03) \\
10400\end{array}$ & $\begin{array}{l}0.12^{\star *} \\
(0.03) \\
10400\end{array}$ & $\begin{array}{l}0.08^{\star *} \\
(0.03) \\
10400\end{array}$ & $\begin{array}{l}0.07^{* *} \\
(0.03) \\
10400\end{array}$ \\
\hline $\begin{array}{l}\text { Cohort } 6 \\
(1993)\end{array}$ & $\begin{array}{l}\text { Coefficient } \\
\text { (s.e.) } \\
\text { Observations }\end{array}$ & $\begin{array}{l}0.16^{* *} \\
(0.03) \\
10253\end{array}$ & $\begin{array}{l}0.06^{* *} \\
(0.03) \\
10253\end{array}$ & $\begin{array}{l}0.06^{*} \\
(0.03) \\
10253\end{array}$ & $\begin{array}{l}0.08^{* *} \\
(0.03) \\
10253\end{array}$ & $\begin{array}{l}--- \\
--- \\
---\end{array}$ \\
\hline & Results with & t lost obs & tions & & & \\
\hline $\begin{array}{l}\text { Cohort } 3 \\
\text { (1996) }\end{array}$ & $\begin{array}{l}\text { Coefficient } \\
\text { (s.e.) } \\
\text { Observations }\end{array}$ & $\begin{array}{l}0.13^{* *} \\
(0.03) \\
10926\end{array}$ & $\begin{array}{l}0.13^{\star *} \\
(0.03) \\
10947\end{array}$ & $\begin{array}{l}0.12^{\star *} \\
(0.03) \\
11049\end{array}$ & $\begin{array}{l}0.14^{* *} \\
(0.03) \\
10905\end{array}$ & $\begin{array}{l}0.15^{\star *} \\
(0.04) \\
9853\end{array}$ \\
\hline $\begin{array}{l}\text { Cohort } 4 \\
\text { (1995) }\end{array}$ & $\begin{array}{l}\text { Coefficient } \\
\text { (s.e.) } \\
\text { Observations }\end{array}$ & $\begin{array}{l}0.19^{* *} \\
(0.03) \\
11064\end{array}$ & $\begin{array}{l}0.15^{\star *} \\
(0.03) \\
11078\end{array}$ & $\begin{array}{l}0.14^{* *} \\
(0.03) \\
10788\end{array}$ & $\begin{array}{l}0.09^{* *} \\
(0.04) \\
10001\end{array}$ & $\begin{array}{l}0.09^{* *} \\
(0.03) \\
9345\end{array}$ \\
\hline $\begin{array}{l}\text { Cohort } 5 \\
(1994)\end{array}$ & $\begin{array}{l}\text { Coefficient } \\
\text { (s.e.) } \\
\text { Observations }\end{array}$ & $\begin{array}{l}0.14^{\star *} \\
(0.03) \\
10753\end{array}$ & $\begin{array}{l}0.13^{* *} \\
(0.03) \\
10400\end{array}$ & $\begin{array}{l}0.14^{\star *} \\
(0.03) \\
10054\end{array}$ & $\begin{array}{l}0.13^{\star *} \\
(0.04) \\
8872\end{array}$ & $\begin{array}{l}0.12^{\star *} \\
(0.04) \\
8086\end{array}$ \\
\hline $\begin{array}{l}\text { Cohort } 6 \\
\text { (1993) }\end{array}$ & $\begin{array}{l}\text { Coefficient } \\
\text { (s.e.) } \\
\text { Observations }\end{array}$ & $\begin{array}{l}0.16^{* *} \\
(0.03) \\
10253\end{array}$ & $\begin{array}{l}0.09^{* *} \\
(0.03) \\
9464\end{array}$ & $\begin{array}{l}0.13^{* *} \\
(0.03) \\
8722\end{array}$ & $\begin{array}{l}0.11^{* *} \\
(0.04) \\
7812\end{array}$ & $\begin{array}{l}--- \\
--- \\
---\end{array}$ \\
\hline
\end{tabular}

Note: Two-stage least squares regressions of a binary indicator for attending general grammar school or vocational grammar school leading to a general college/university entry certificate (berufliches Gymnasium) on school entry age, instrumented by assigned school entry age. *Significant at the 10 percent level. ** Significant at the five percent level. Documented coefficients refer to specifications without control variables. Effects are robust if available control variables (gender, region and nationality) are considered. The upper panel of the estimates includes simulation results holding the number of observations constant for grades 10 to 13 (see Section 3.3). Missing observations are assumed to be lower track students since they would be in the data if they had sought a higher secondary diploma. The lower panel of the estimates shows the results based only on observed students without simulated observations.

Source: Student-level data of the statistics on general and vocational schools for the state of Hessen 2002/03 to 2006/07 provided by the Hessen State Statistical Office (Hessisches Statistisches Landesamt). Authors' own calculations. 
Table 12: School Attendance by Birth Month Twelve Years After School EntryPopulation of Students Born in June or July

\begin{tabular}{llccc}
\hline \hline Cohort & School Type & $\begin{array}{c}\text { June- } \\
\text { born } \\
(\%)\end{array}$ & $\begin{array}{l}\text { July- } \\
\text { born } \\
(\%)\end{array}$ & $\begin{array}{l}\text { Differ- } \\
\text { ence }\end{array}$ \\
\hline Cohort 4 & General grammar school (Gymnasium) & 31.5 & 33.8 & $-2.3^{* *}$ \\
(1995) & Vocational grammar school (berufliches Gymnasium) & 5.4 & 4.8 & 0.7 \\
& Lower-level vocational grammar school (Fachoberschule) & 14.5 & 14.2 & 0.3 \\
& Nongrammar track & 48.6 & 47.2 & 1.4 \\
& Observations & 5240 & 5548 & \\
Cohort 5 & General grammar school (Gymnasium) & 30.6 & 33.0 & $-2.2^{* *}$ \\
$(1994)$ & Vocational grammar school (berufliches Gymnasium) & 4.9 & 4.9 & 0.0 \\
& Lower-level vocational grammar school (Fachoberschule) & 14.2 & 12.6 & $1.6^{* *}$ \\
& Nongrammar track & 50.3 & 49.5 & 0.8 \\
& Observations & 5007 & 5393 & \\
Cohort 6 & General grammar school (Gymnasium) & 30.5 & 32.4 & $-2.0^{* *}$ \\
(1993) & Vocational grammar school (berufliches Gymnasium) & 5.0 & 4.8 & 0.2 \\
& Lower-level vocational grammar school (Fachoberschule) & 13.3 & 11.4 & $1.9^{* *}$ \\
& Nongrammar track & 51.2 & 51.4 & -0.2 \\
\hline \hline & Observations & 5090 & 5163 & \\
\hline \hline
\end{tabular}

Note: Years below the cohort numbers designate the year of school entry. ${ }^{* *}$ Difference in means between Juneand July-born is significant at the five percent level. Lower-level vocational grammar schools only lead to college access (similar to former British polytechnics), whereas vocational grammar schools called berufliches Gymnasium offer general grammar school certificates equivalent to those of general (traditional) grammar schools in Hessen. The latter allow entry both into colleges and universities.

Source: Student-level data of the statistics on general and vocational schools for the state of Hessen 2004/05 to 2006/07 provided by the Hessen State Statistical Office (Hessisches Statistisches Landesamt). Authors' own calculations.

Table 13: Returns to a Grammar School Certificate

\begin{tabular}{|c|c|c|c|c|c|c|c|c|}
\hline & Men & & & & Women & & & \\
\hline & GSOEP & & $M Z$ & & GSOEP & & $M Z$ & \\
\hline Any Grammar School Certific. & $0.21^{* *}$ & $0.19^{* *}$ & $0.25^{* *}$ & $0.20^{* *}$ & $0.24^{* *}$ & $0.24^{* *}$ & $0.26^{* *}$ & $0.17^{* *}$ \\
\hline (s.e.) & $(0.04)$ & $(0.07)$ & $(0.01)$ & $(0.01)$ & $(0.05)$ & $(0.08)$ & $(0.01)$ & $(0.02)$ \\
\hline Grammar no Fachoberschule & --- & 0.03 & --- & $0.08^{* *}$ & --- & -0.01 & --- & $0.11^{* *}$ \\
\hline (s.e.) & --- & $(0.08)$ & --- & $(0.01)$ & --- & $(0.09)$ & --- & $(0.02)$ \\
\hline Age & $0.15^{*}$ & $0.15^{\star}$ & $0.09^{* *}$ & $0.09^{* *}$ & 0.07 & 0.07 & $0.03^{* *}$ & $0.03^{* *}$ \\
\hline (s.e.) & $(0.08)$ & $(0.08)$ & $(0.01)$ & $(0.01)$ & $(0.10)$ & $(0.10)$ & $(0.01)$ & $(0.01)$ \\
\hline Age squared & 0.00 & 0.00 & $0.00^{* *}$ & $0.00^{* *}$ & 0.00 & 0.00 & $0.00^{* *}$ & $0.00^{* *}$ \\
\hline (s.e.) & $(0.00)$ & $(0.00)$ & $(0.00)$ & $(0.00)$ & $(0.00)$ & $(0.00)$ & $(0.00)$ & $(0.00)$ \\
\hline constant & -0.65 & -0.65 & 0.33 & 0.33 & 1.07 & 1.06 & $1.15^{* *}$ & $1.16^{* *}$ \\
\hline (s.e.) & $(1.31)$ & $(1.32)$ & $(0.18)$ & $(0.18)$ & $(1.61)$ & $(1.60)$ & $(0.24)$ & $(0.24)$ \\
\hline Obs & 1462 & 1462 & 32507 & 32507 & 1172 & 1172 & 23459 & 23459 \\
\hline $\mathrm{R}^{2}$ (GSOEP)/Pseudo-R ${ }^{2}(\mathrm{MZ})$ & 0.13 & 0.13 & 0.02 & 0.02 & 0.06 & 0.06 & 0.01 & 0.01 \\
\hline
\end{tabular}

Note: The dependent variable is the natural logarithm of the gross hourly wage rate (GSOEP) or net hourly income (MZ). Only West Germans aged 26 to 40 are included in the sample. Any Grammar School Diploma is a dummy variable that equals 1 if a person holds a diploma obtained from traditional Gymnasium, berufliches Gymnasium, or Fachoberschule. Grammar no Fachoberschule is a dummy variable that equals 1 if a person holds a diploma obtained from traditional Gymnasium or berufliches Gymnasium.Neither the German SocioEconomic Panel nor the Mikrozensus distinguish between certificates from traditional Gymnasium and berufliches Gymnasium. Estimates are obtained using sampling weights and robust standard errors. Because income in the Mikrozensus is given in intervals, we estimate interval regressions (ordered probit with known boundaries) instead of ordinary least squares regressions.

*Significant at the 10 percent level. ${ }^{*}$ Significant at the 5 percent level.

Source: German Socio-Economic Panel (GSOEP) and Mikrozensus (MZ) 2004. Authors' own calculations. 
Figure 1: The Hamburg Accord and Educational Outcomes

Actual and Assigned School Entry Ages by Birth Month

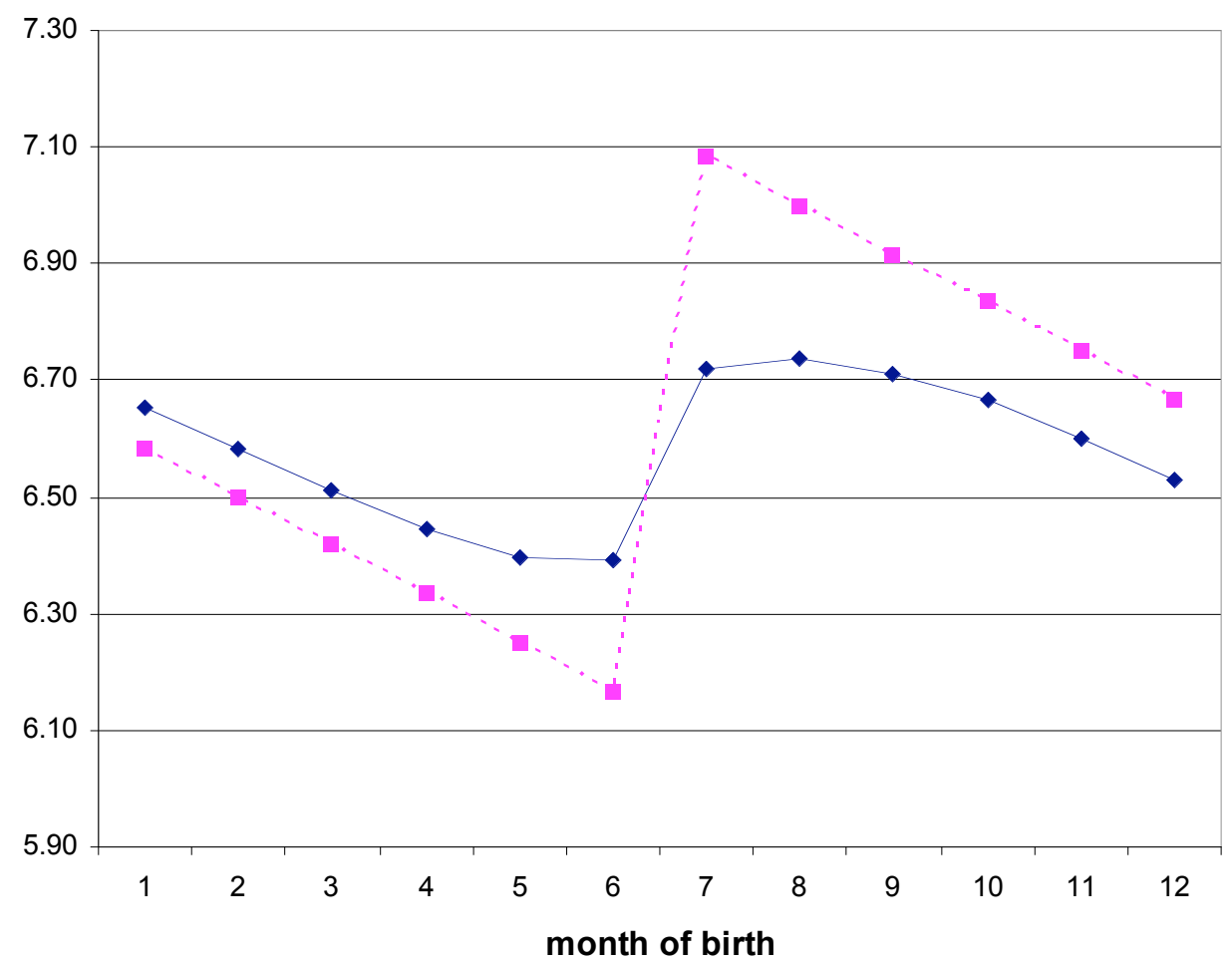

$\longrightarrow$ actual age ....... assigned age

Grammar School Attendance by Birth Month

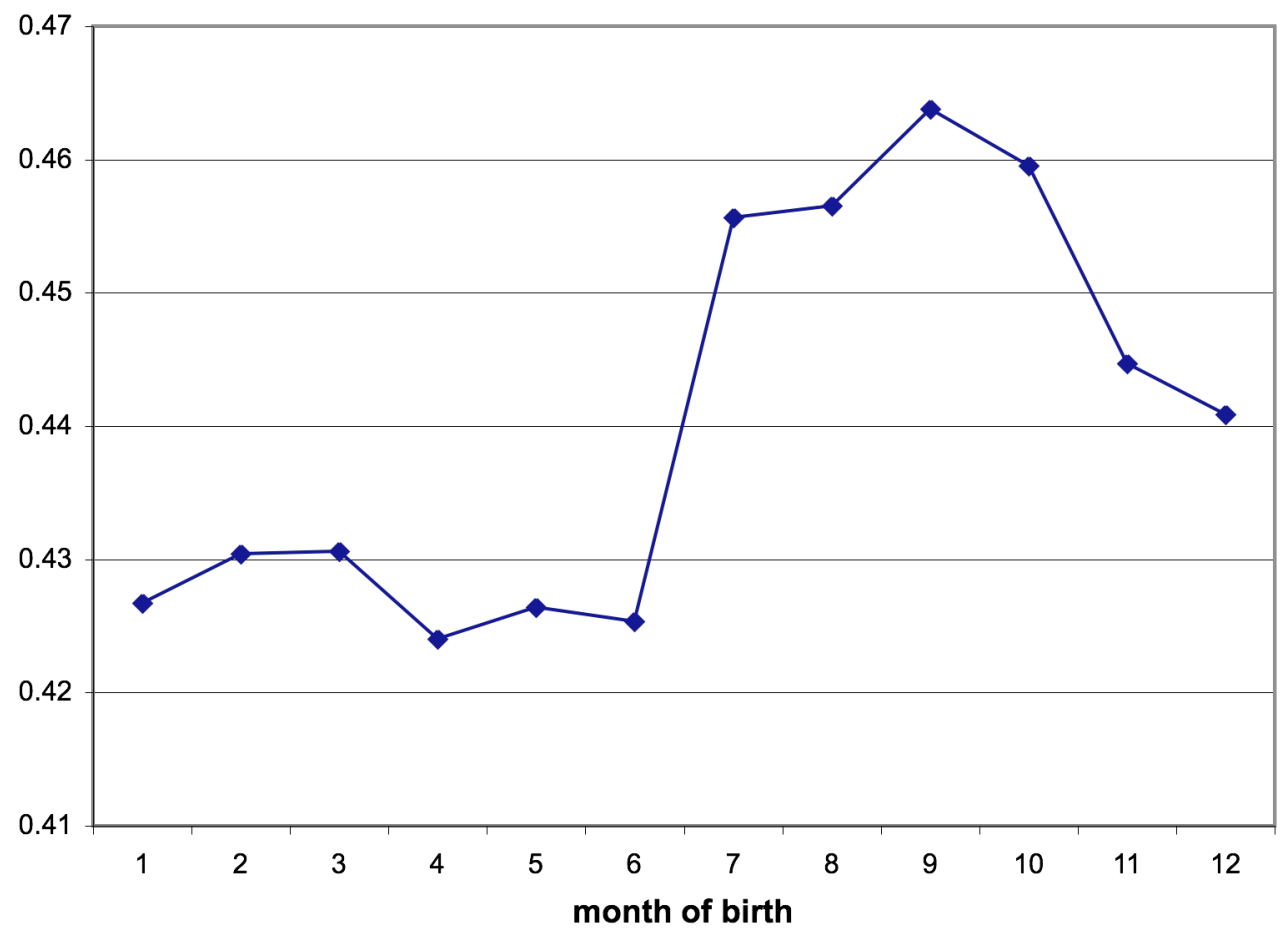

Source: Student-level data of the statistics on general and vocational schools for the state of Hessen 2005/06 provided by the Hessen State Statistical Office (Hessisches Statistisches Landesamt), cohorts entering elementary school in 1993-1998. Authors' own calculations. 
Figure 2: $\quad$ Distribution of Actual and Assigned School Entry Age
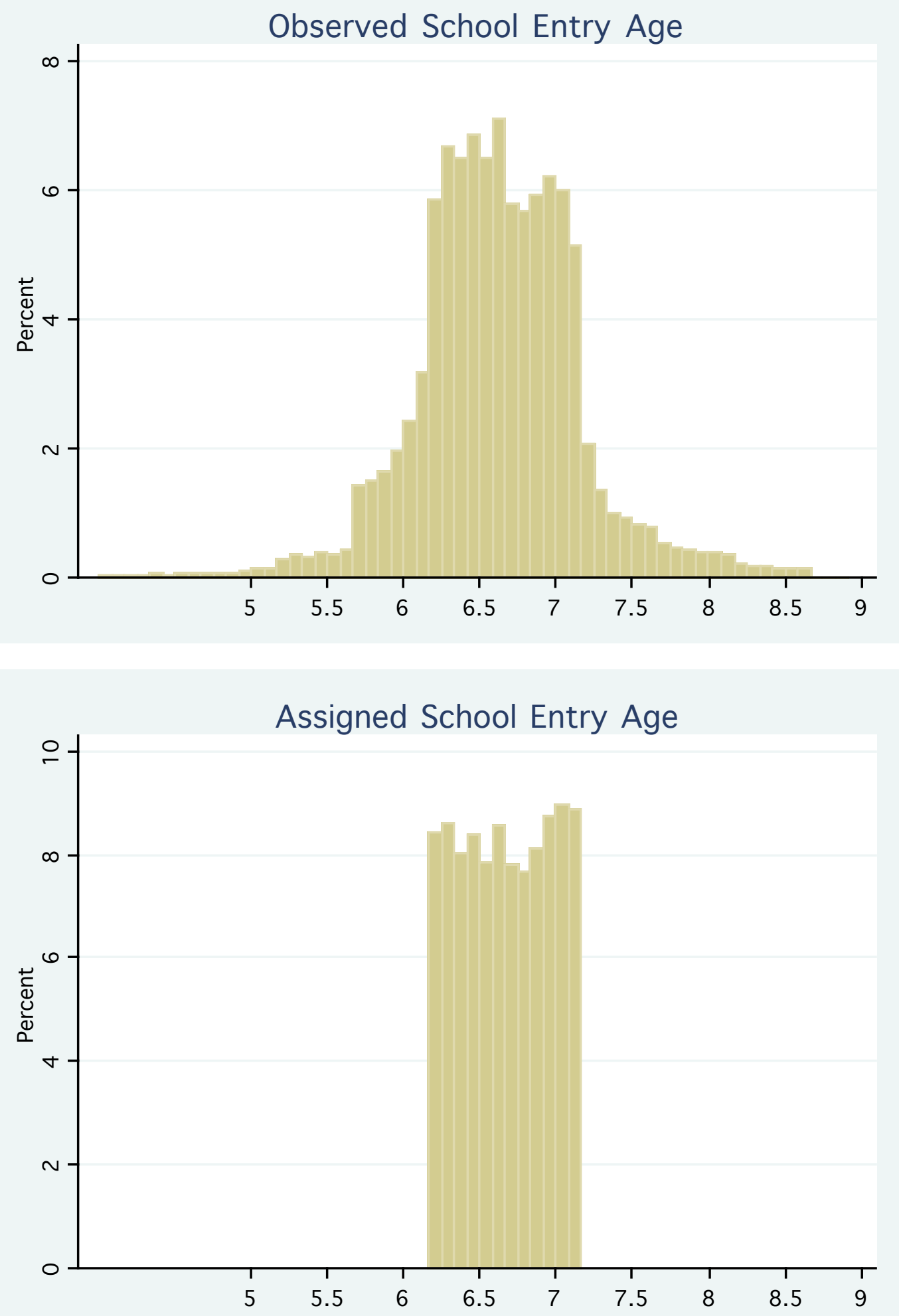

Note: Assigned school entry age according to the Hamburg Accord.

Source: Student-level data of the statistics on general and vocational schools for the state of Hessen 2005/06 provided by the Hessen State Statistical Office (Hessisches Statistisches Landesamt), cohorts entering elementary school in 1993-1998. Authors' own calculations. 


\section{Appendix}

Table A1: Simple Correlations Between Instrument and Observables-Full Population

\begin{tabular}{|c|c|c|c|c|c|}
\hline \multirow{2}{*}{ Cohort 1: } & \multicolumn{5}{|c|}{$2002 / 3$ 2003/4 2004/5 2005/6 2006/7 } \\
\hline & & & & & \\
\hline Male & 0.00 & 0.00 & 0.00 & 0.00 & 0.00 \\
\hline Region: Darmstadt & 0.00 & 0.00 & 0.00 & 0.00 & 0.00 \\
\hline Region: Frankfurt & $-0.01^{* *}$ & 0.00 & $-0.01^{*}$ & $-0.01^{* *}$ & * $-0.01^{*}$ \\
\hline Region: Offenbach, Offenbach-Land & 0.00 & 0.00 & 0.01 & 0.01 & 0.00 \\
\hline Region: Wiesbaden, Main-Taunus, Rheingau-Taunus & 0.00 & 0.00 & 0.00 & 0.00 & 0.00 \\
\hline Region: Bergstraße, Odenwald, Dieburg, Groß-Gerau & 0.00 & 0.00 & 0.00 & 0.00 & 0.00 \\
\hline Region: Hochtaunus, Wetterau & 0.00 & 0.01 & $0.01^{*}$ & $0.01^{*}$ & 0.01 \\
\hline Region: Main-Kinzig & 0.00 & 0.00 & 0.00 & 0.00 & 0.00 \\
\hline Region: Gießen, Lahn-Dill, Limburg-Weilburg & -0.01 & 0.00 & 0.00 & 0.00 & 0.00 \\
\hline Region: Marburg-Biedenkopf, Vogelsberg & 0.00 & 0.00 & 0.00 & 0.00 & 0.00 \\
\hline Region: Kassel & 0.00 & 0.00 & 0.00 & 0.00 & 0.01 \\
\hline Region: Fulda, Hersfeld-Rotenburg & 0.00 & 0.00 & 0.00 & 0.00 & 0.00 \\
\hline Region: Kassel-Ld., Werra-Meißner, Schwalm-Eder, Waldeck-F. & 0.00 & -0.01 & -0.01 & -0.01 & 0.00 \\
\hline Nationality: German speaking countries & $0.01^{* *}$ & $0.01^{* *}$ & $0.01^{* *}$ & ${ }^{*} 0.01^{* *}$ & * $0.02^{* *}$ \\
\hline Nationality: Turkey & $-0.02^{* *}$ & $-0.02^{* *}$ & $-0.01^{* *}$ & ${ }^{*}-0.02^{* *}$ & * $-0.02^{* *}$ \\
\hline Nationality: Italy, Greece & -0.01 & 0.00 & -0.01 & -0.01 & -0.01 \\
\hline Nationality: Former Yugoslavian states & 0.00 & 0.00 & 0.00 & 0.01 & $0.01^{*}$ \\
\hline Nationality: Remaining Western countries & 0.00 & 0.01 & 0.00 & 0.00 & 0.00 \\
\hline Nationality: Eastern Europe, former Soviet Union & 0.00 & 0.00 & 0.00 & 0.00 & -0.01 \\
\hline Nationality: Remaining Muslim countries & 0.00 & 0.00 & -0.01 & 0.00 & 0.00 \\
\hline Nationality: Remaining Asia & 0.00 & 0.00 & 0.01 & 0.00 & 0.00 \\
\hline Nationality: Remaining countries & 0.00 & 0.00 & 0.00 & -0.01 & 0.00 \\
\hline \multicolumn{6}{|l|}{ Cohort 6: } \\
\hline Male & -0.01 & -0.01 & 0.00 & 0.00 & --- \\
\hline Region: Darmstadt & 0.00 & 0.00 & $-0.01^{* *}$ & ${ }^{*}-0.01^{*}$ & --- \\
\hline Region: Frankfurt & $0.01^{*}$ & $0.01^{* *}$ & 0.01 & 0.00 & --- \\
\hline Region: Offenbach, Offenbach-Land & 0.00 & $-0.01^{*}$ & 0.00 & 0.01 & --- \\
\hline Region: Wiesbaden, Main-Taunus, Rheingau-Taunus & 0.00 & 0.00 & 0.00 & 0.00 & --- \\
\hline Region: Bergstraße, Odenwald, Dieburg, Groß-Gerau & 0.00 & 0.00 & 0.00 & 0.00 & --- \\
\hline Region: Hochtaunus, Wetterau & 0.01 & $0.01^{* *}$ & 0.01 & 0.00 & --- \\
\hline Region: Main-Kinzig & 0.00 & 0.00 & $-0.01^{*}$ & $-0.01^{*}$ & --- \\
\hline Region: Gießen, Lahn-Dill, Limburg-Weilburg & $-0.01^{*}$ & 0.00 & 0.00 & 0.00 & --- \\
\hline Region: Marburg-Biedenkopf, Vogelsberg & $0.01^{* *}$ & $0.01^{* *}$ & 0.01 & 0.00 & --- \\
\hline Region: Kassel & 0.00 & 0.00 & 0.00 & 0.00 & --- \\
\hline Region: Fulda, Hersfeld-Rotenburg & -0.01 & $-0.01^{*}$ & 0.00 & 0.01 & --- \\
\hline Region: Kassel-Ld., Werra-Meißner, Schwalm-Eder, Waldeck-F. & 0.00 & 0.00 & 0.00 & 0.00 & --- \\
\hline Nationality: German speaking countries & $0.01^{* *}$ & 0.01 & 0.01 & 0.00 & --- \\
\hline Nationality: Turkey & $-0.01^{*}$ & $-0.01^{*}$ & $-0.01^{*}$ & -0.01 & --- \\
\hline Nationality: Italy, Greece & 0.00 & $0.01^{* *}$ & * 0.00 & 0.00 & --- \\
\hline Nationality: Former Yugoslavian states & 0.00 & 0.00 & 0.00 & 0.00 & --- \\
\hline Nationality: Remaining Western countries & 0.00 & -0.01 & 0.00 & 0.00 & --- \\
\hline Nationality: Eastern Europe, former Soviet Union & 0.00 & -0.01 & 0.00 & 0.00 & --- \\
\hline Nationality: Remaining Muslim countries & -0.01 & 0.00 & 0.00 & 0.00 & --- \\
\hline Nationality: Remaining Asia & 0.00 & 0.00 & 0.01 & 0.00 & --- \\
\hline Nationality: Remaining countries & 0.00 & 0.00 & 0.00 & 0.00 & --- \\
\hline
\end{tabular}

Note: *Significant at the 10 percent level. ${ }^{*}$ Significant at the 5 percent level. Information on cohort 6 in 2006/07 is missing since these students would have to be in grade 14 (which does not exist).

Source: Student-level data of the statistics on general and vocational schools for Hessen 2002/03 to 2006/07 provided by the Hessen State Statistical Office (Hessisches Statistisches Landesamt). Authors' own calculations. 
Table A2: First-Stage Results-Full Population of Students

\begin{tabular}{|c|c|c|c|c|c|c|}
\hline & & $2002 / 03$ & $2003 / 04$ & $2004 / 05$ & $2005 / 06$ & $2006 / 07$ \\
\hline $\begin{array}{l}\text { Cohort } 1 \\
(1998)\end{array}$ & $\begin{array}{l}\text { Coefficient } \\
\text { (F) } \\
\text { Observations }\end{array}$ & $\begin{array}{l}0.44^{* *} \\
(3904) \\
62832\end{array}$ & $\begin{array}{l}0.48^{* *} \\
(4391) \\
61438\end{array}$ & $\begin{array}{l}0.48^{\star *} \\
(4173) \\
61552\end{array}$ & $\begin{array}{l}0.47^{* *} \\
(3958) \\
61398\end{array}$ & $\begin{array}{l}0.44^{* *} \\
(3404) \\
61947\end{array}$ \\
\hline $\begin{array}{l}\text { Cohort } 2 \\
(1997)\end{array}$ & $\begin{array}{l}\text { Coefficient } \\
\text { (F) } \\
\text { Observations }\end{array}$ & $\begin{array}{l}0.49 * * \\
(4552) \\
59194\end{array}$ & $\begin{array}{l}0.49 * * \\
(4190) \\
59834\end{array}$ & $\begin{array}{l}0.48 * * \\
(4095) \\
60114\end{array}$ & $\begin{array}{l}0.48^{* *} \\
(3911) \\
60917\end{array}$ & $\begin{array}{l}0.46 * * \\
(3509) \\
59628\end{array}$ \\
\hline $\begin{array}{l}\text { Cohort } 3 \\
(1996)\end{array}$ & $\begin{array}{l}\text { Coefficient } \\
\text { (F) } \\
\text { Observations }\end{array}$ & $\begin{array}{l}0.32^{* *} \\
(1858) \\
63425\end{array}$ & $\begin{array}{l}0.32 * * \\
(1889) \\
63621\end{array}$ & $\begin{array}{l}0.33^{* *} \\
(1790) \\
63937\end{array}$ & $\begin{array}{l}0.33^{* *} \\
(1707) \\
63240\end{array}$ & $\begin{array}{l}0.31 * * \\
(1525) \\
63240\end{array}$ \\
\hline $\begin{array}{l}\text { Cohort } 4 \\
(1995)\end{array}$ & $\begin{array}{l}\text { Coefficient } \\
\text { (F) } \\
\text { Observations }\end{array}$ & $\begin{array}{l}0.32^{* *} \\
(1918) \\
64037\end{array}$ & $\begin{array}{l}0.32 * * \\
(1870) \\
64003\end{array}$ & $\begin{array}{l}0.33^{* *} \\
(1970) \\
62735\end{array}$ & $\begin{array}{l}0.33^{* *} \\
(1881) \\
62735\end{array}$ & $\begin{array}{l}0.34 * * \\
(1795) \\
62735\end{array}$ \\
\hline $\begin{array}{l}\text { Cohort } 5 \\
(1994)\end{array}$ & $\begin{array}{l}\text { Coefficient } \\
\text { (F) } \\
\text { Observations }\end{array}$ & $\begin{array}{l}0.34^{* *} \\
(2210) \\
62673\end{array}$ & $\begin{array}{l}0.34 * * \\
(2167) \\
60941\end{array}$ & $\begin{array}{l}0.35^{* *} \\
(2096) \\
60941\end{array}$ & $\begin{array}{l}0.34 * * \\
(1946) \\
60941\end{array}$ & $\begin{array}{l}0.33^{* *} \\
(1746) \\
60941\end{array}$ \\
\hline $\begin{array}{l}\text { Cohort } 6 \\
(1993)\end{array}$ & $\begin{array}{l}\text { Coefficient } \\
\text { (F) } \\
\text { Observations }\end{array}$ & $\begin{array}{l}0.34^{* *} \\
(1961) \\
58599\end{array}$ & $\begin{array}{l}0.35^{* *} \\
(1987) \\
58599\end{array}$ & $\begin{array}{l}0.35^{* *} \\
(1915) \\
58599\end{array}$ & $\begin{array}{l}0.33^{* *} \\
(1734) \\
58599\end{array}$ & $\begin{array}{l}--- \\
--- \\
---\end{array}$ \\
\hline & \multicolumn{6}{|c|}{ Results without lost observations } \\
\hline $\begin{array}{l}\text { Cohort } 3 \\
(1996)\end{array}$ & $\begin{array}{l}\text { Coefficient } \\
\text { (F) } \\
\text { Observations }\end{array}$ & $\begin{array}{l}0.32^{* *} \\
(1858) \\
63425\end{array}$ & $\begin{array}{l}0.32^{* *} \\
(1889) \\
63621\end{array}$ & $\begin{array}{l}0.33^{* *} \\
(1790) \\
63937\end{array}$ & $\begin{array}{l}0.33^{* *} \\
(1707) \\
63240\end{array}$ & $\begin{array}{l}0.31^{* *} \\
(1363) \\
57890\end{array}$ \\
\hline $\begin{array}{l}\text { Cohort } 4 \\
(1995)\end{array}$ & $\begin{array}{l}\text { Coefficient } \\
\text { (F) } \\
\text { Observations }\end{array}$ & $\begin{array}{l}0.32 * * \\
(1918) \\
64037\end{array}$ & $\begin{array}{l}0.32^{* *} \\
(1870) \\
64003\end{array}$ & $\begin{array}{l}0.33^{* *} \\
(1970) \\
62735\end{array}$ & $\begin{array}{l}0.32 * * \\
(1612) \\
58557\end{array}$ & $\begin{array}{l}0.34^{* *} \\
(1500) \\
54669\end{array}$ \\
\hline $\begin{array}{l}\text { Cohort } 5 \\
(1994)\end{array}$ & $\begin{array}{l}\text { Coefficient } \\
\text { (F) } \\
\text { Observations }\end{array}$ & $\begin{array}{l}0.34^{* *} \\
(2210) \\
62673\end{array}$ & $\begin{array}{l}0.34 * * \\
(2167) \\
60941\end{array}$ & $\begin{array}{l}0.33^{* *} \\
(1812) \\
58700\end{array}$ & $\begin{array}{l}0.35^{* *} \\
(1696) \\
51945\end{array}$ & $\begin{array}{l}0.34 * * \\
(1285) \\
47305\end{array}$ \\
\hline $\begin{array}{l}\text { Cohort } 6 \\
(1993)\end{array}$ & $\begin{array}{l}\text { Coefficient } \\
\text { (F) } \\
\text { Observations }\end{array}$ & $\begin{array}{l}0.34^{* *} \\
(1961) \\
58599\end{array}$ & $\begin{array}{l}0.34^{* *} \\
(1723) \\
54887\end{array}$ & $\begin{array}{l}0.38 * * \\
(1925) \\
51390\end{array}$ & $\begin{array}{l}0.37^{* *} \\
(1472) \\
44653\end{array}$ & $\begin{array}{l}--- \\
--- \\
---\end{array}$ \\
\hline
\end{tabular}

Note: *Significant at the 10 percent level. ${ }^{* \star}$ Significant at the 5 percent level. Documented coefficients refer to specifications without control variables. Effects are robust if available control variables (gender, region, and nationality) are considered. The upper panel of the estimates includes simulation results holding the number of observations constant for grades 10 to 13 (see Section 3.3). Missing observations are assumed to be lower track students since they would be in the data if they had sought a higher secondary diploma. The lower panel of the estimates shows the results based only on observed students without simulated observations.

Source: Student-level data of the statistics on general and vocational schools for the state of Hessen 2002/03 to 2006/07 provided by the Hessen State Statistical Office (Hessisches Statistisches Landesamt). Authors' own calculations. 
Table A3: OLS Results-Full Population of Students

\begin{tabular}{|c|c|c|c|c|c|c|}
\hline & & $2002 / 03$ & $2003 / 04$ & $2004 / 05$ & $2005 / 06$ & $2006 / 07$ \\
\hline $\begin{array}{l}\text { Cohort } 1 \\
(1998)\end{array}$ & $\begin{array}{l}\text { Coefficient } \\
\text { (s.e.) } \\
\text { Observations }\end{array}$ & $\begin{array}{l}-0.01 \\
(0.00) \\
62832\end{array}$ & $\begin{array}{l}-0.11^{\star *} \\
(0.00) \\
61438\end{array}$ & $\begin{array}{l}-0.13^{\star \star} \\
(0.00) \\
61552\end{array}$ & $\begin{array}{l}-0.13^{* *} \\
(0.00) \\
61398\end{array}$ & $\begin{array}{l}-0.14^{* *} \\
(0.00) \\
61947\end{array}$ \\
\hline $\begin{array}{l}\text { Cohort } 2 \\
(1997)\end{array}$ & $\begin{array}{l}\text { Coefficient } \\
\text { (s.e.) } \\
\text { Observations }\end{array}$ & $\begin{array}{l}-0.12^{* *} \\
(0.00) \\
59194\end{array}$ & $\begin{array}{l}-0.12^{* *} \\
(0.00) \\
59834\end{array}$ & $\begin{array}{l}-0.13^{* *} \\
(0.00) \\
60114\end{array}$ & $\begin{array}{l}-0.13^{* *} \\
(0.00) \\
60917\end{array}$ & $\begin{array}{l}-0.11^{* *} \\
(0.00) \\
59628\end{array}$ \\
\hline $\begin{array}{l}\text { Cohort } 3 \\
\text { (1996) }\end{array}$ & $\begin{array}{l}\text { Coefficient } \\
\text { (s.e.) } \\
\text { Observations }\end{array}$ & $\begin{array}{l}-0.11^{* *} \\
(0.00) \\
63425\end{array}$ & $\begin{array}{l}-0.14^{* *} \\
(0.00) \\
63621\end{array}$ & $\begin{array}{l}-0.14^{* *} \\
(0.00) \\
63937\end{array}$ & $\begin{array}{l}-0.12^{* *} \\
(0.00) \\
63240\end{array}$ & $\begin{array}{l}-0.00 \\
(0.00) \\
63240\end{array}$ \\
\hline $\begin{array}{l}\text { Cohort } 4 \\
\text { (1995) }\end{array}$ & $\begin{array}{l}\text { Coefficient } \\
\text { (s.e.) } \\
\text { Observations }\end{array}$ & $\begin{array}{l}-0.14^{* *} \\
(0.00) \\
64037\end{array}$ & $\begin{array}{l}-0.15^{\star *} \\
(0.00) \\
64003\end{array}$ & $\begin{array}{l}-0.14^{* *} \\
(0.00) \\
62735\end{array}$ & $\begin{array}{l}-0.02 * * \\
(0.00) \\
62735\end{array}$ & $\begin{array}{l}-0.00 \\
(0.00) \\
62735\end{array}$ \\
\hline $\begin{array}{l}\text { Cohort } 5 \\
(1994)\end{array}$ & $\begin{array}{l}\text { Coefficient } \\
\text { (s.e.) } \\
\text { Observations }\end{array}$ & $\begin{array}{l}-0.12^{\star *} \\
(0.00) \\
62673\end{array}$ & $\begin{array}{l}-0.10 * * \\
(0.00) \\
60941\end{array}$ & $\begin{array}{l}0.00 \\
(0.00) \\
60941\end{array}$ & $\begin{array}{l}-0.02 * * \\
(0.00) \\
60941\end{array}$ & $\begin{array}{l}-0.05^{\star *} \\
(0.00) \\
60941\end{array}$ \\
\hline $\begin{array}{l}\text { Cohort } 6 \\
(1993)\end{array}$ & $\begin{array}{l}\text { Coefficient } \\
\text { (s.e.) } \\
\text { Observations }\end{array}$ & $\begin{array}{l}-0.10^{* *} \\
(0.00) \\
58599\end{array}$ & $\begin{array}{l}-0.01 * \\
(0.00) \\
58599\end{array}$ & $\begin{array}{l}-0.02^{* *} \\
(0.00) \\
58599\end{array}$ & $\begin{array}{l}-0.05^{\star *} \\
(0.00) \\
58599\end{array}$ & $\begin{array}{l}--- \\
--- \\
---\end{array}$ \\
\hline \multicolumn{7}{|c|}{ Results without lost observations } \\
\hline $\begin{array}{l}\text { Cohort } 3 \\
(1996)\end{array}$ & $\begin{array}{l}\text { Coefficient } \\
\text { (s.e.) } \\
\text { Observations }\end{array}$ & $\begin{array}{l}-0.11^{* *} \\
(0.00) \\
63425\end{array}$ & $\begin{array}{l}-0.14^{* *} \\
(0.00) \\
63621\end{array}$ & $\begin{array}{l}-0.14^{* *} \\
(0.00) \\
63937\end{array}$ & $\begin{array}{l}-0.12^{* *} \\
(0.00) \\
63240\end{array}$ & $\begin{array}{l}0.02 \\
(0.00) \\
57890\end{array}$ \\
\hline $\begin{array}{l}\text { Cohort } 4 \\
\text { (1995) }\end{array}$ & $\begin{array}{l}\text { Coefficient } \\
\text { (s.e.) } \\
\text { Observations }\end{array}$ & $\begin{array}{l}-0.14^{* *} \\
(0.00) \\
64037\end{array}$ & $\begin{array}{l}-0.15^{\star *} \\
(0.00) \\
64003\end{array}$ & $\begin{array}{l}-0.14^{\star *} \\
(0.00) \\
62735\end{array}$ & $\begin{array}{l}-0.02 * * \\
(0.00) \\
58557\end{array}$ & $\begin{array}{l}0.02 \\
(0.00) \\
54669\end{array}$ \\
\hline $\begin{array}{l}\text { Cohort } 5 \\
(1994)\end{array}$ & $\begin{array}{l}\text { Coefficient } \\
\text { (s.e.) } \\
\text { Observations }\end{array}$ & $\begin{array}{l}-0.12^{* *} \\
(0.00) \\
62673\end{array}$ & $\begin{array}{l}-0.10^{* *} \\
(0.00) \\
60941\end{array}$ & $\begin{array}{l}0.01 * \\
(0.00) \\
58700\end{array}$ & $\begin{array}{l}0.02 * * \\
(0.00) \\
51945\end{array}$ & $\begin{array}{l}0.00 * \\
(0.00) \\
47305\end{array}$ \\
\hline $\begin{array}{l}\text { Cohort } 6 \\
\text { (1993) }\end{array}$ & $\begin{array}{l}\text { Coefficient } \\
\text { (s.e.) } \\
\text { Observations }\end{array}$ & $\begin{array}{l}-0.10 * * \\
(0.00) \\
58599\end{array}$ & $\begin{array}{l}0.00 \\
(0.00) \\
54887\end{array}$ & $\begin{array}{l}0.02 * * \\
(0.00) \\
51390\end{array}$ & $\begin{array}{l}0.01 \\
(0.00) \\
44653\end{array}$ & $\begin{array}{l}--- \\
--- \\
---\end{array}$ \\
\hline
\end{tabular}

Note: OLS regressions of a binary indicator for attending grammar school on school entry age. * Significant at the 10 percent level. ${ }^{* *}$ Significant at the 5 percent level. Documented coefficients refer to specifications without control variables. Effects are robust if available control variables (gender, region, and nationality) are considered. The upper panel of the estimates includes simulation results holding the number of observations constant for grades 10 to 13 (see Section 3.3). Missing observations are assumed to be lower track students since they would be in the data if they had sought a higher secondary diploma. The lower panel of the estimates shows the results based only on observed students without simulated observations.

Source: Student-level data of the statistics on general and vocational schools for the state of Hessen 2002/03 to 2006/07 provided by the Hessen State Statistical Office (Hessisches Statistisches Landesamt). Authors' own calculations. 
Table A4: Second-Stage Results-Full Population of Students

\begin{tabular}{|c|c|c|c|c|c|c|}
\hline & & $2002 / 03$ & $2003 / 04$ & $2004 / 05$ & 2005/06 & $2006 / 07$ \\
\hline $\begin{array}{l}\text { Cohort } 1 \\
(1998)\end{array}$ & $\begin{array}{l}\text { Coefficient } \\
\text { (s.e.) } \\
\text { Observations }\end{array}$ & $\begin{array}{l}0.15^{* *} \\
(0.01) \\
62832\end{array}$ & $\begin{array}{l}0.19 * * \\
(0.01) \\
61438\end{array}$ & $\begin{array}{l}0.19^{* *} \\
(0.01) \\
61552.00\end{array}$ & $\begin{array}{l}0.18^{* *} \\
(0.01) \\
61398\end{array}$ & $\begin{array}{l}0.20 * * \\
(0.02) \\
61947\end{array}$ \\
\hline $\begin{array}{l}\text { Cohort } 2 \\
(1997)\end{array}$ & $\begin{array}{l}\text { Coefficient } \\
\text { (s.e.) } \\
\text { Observations }\end{array}$ & $\begin{array}{l}0.09 * * \\
(0.01) \\
59194\end{array}$ & $\begin{array}{l}0.08^{* *} \\
(0.01) \\
59834\end{array}$ & $\begin{array}{l}0.08 * * \\
(0.01) \\
60114\end{array}$ & $\begin{array}{l}0.08 * * \\
(0.01) \\
60917\end{array}$ & $\begin{array}{l}0.09 * * \\
(0.01) \\
59628\end{array}$ \\
\hline $\begin{array}{l}\text { Cohort } 3 \\
\text { (1996) }\end{array}$ & $\begin{array}{l}\text { Coefficient } \\
\text { (s.e.) } \\
\text { Observations }\end{array}$ & $\begin{array}{l}0.19 * * \\
(0.02) \\
63425\end{array}$ & $\begin{array}{l}0.20^{* *} \\
(0.02) \\
63621\end{array}$ & $\begin{array}{l}0.18 * * \\
(0.02) \\
63937\end{array}$ & $\begin{array}{l}0.18^{* *} \\
(0.02) \\
63240\end{array}$ & $\begin{array}{l}0.08 * * \\
(0.02) \\
63240\end{array}$ \\
\hline $\begin{array}{l}\text { Cohort } 4 \\
\text { (1995) }\end{array}$ & $\begin{array}{l}\text { Coefficient } \\
\text { (s.e.) } \\
\text { Observations }\end{array}$ & $\begin{array}{l}0.23^{* *} \\
(0.02) \\
64037\end{array}$ & $\begin{array}{l}0.21^{* *} \\
(0.02) \\
64003\end{array}$ & $\begin{array}{l}0.17 * * \\
(0.02) \\
62735\end{array}$ & $\begin{array}{l}0.08^{* *} \\
(0.02) \\
62735\end{array}$ & $\begin{array}{l}0.02 \\
(0.02) \\
62735\end{array}$ \\
\hline $\begin{array}{l}\text { Cohort } 5 \\
(1994)\end{array}$ & $\begin{array}{l}\text { Coefficient } \\
\text { (s.e.) } \\
\text { Observations }\end{array}$ & $\begin{array}{l}0.17 * * \\
(0.02) \\
62673\end{array}$ & $\begin{array}{l}0.15^{\star *} \\
(0.02) \\
60941\end{array}$ & $\begin{array}{l}0.09 * * \\
(0.02) \\
60941\end{array}$ & $\begin{array}{l}0.03 \\
(0.02) \\
60941\end{array}$ & $\begin{array}{l}0.01 \\
(0.02) \\
60941\end{array}$ \\
\hline $\begin{array}{l}\text { Cohort } 6 \\
(1993)\end{array}$ & $\begin{array}{l}\text { Coefficient } \\
\text { (s.e.) } \\
\text { Observations }\end{array}$ & $\begin{array}{l}0.22 * * \\
(0.02) \\
58599 \\
\end{array}$ & $\begin{array}{l}0.09 * * \\
(0.02) \\
58599\end{array}$ & $\begin{array}{l}-0.02^{* *} \\
(0.00) \\
58599\end{array}$ & $\begin{array}{l}-0.05^{\star *} \\
(0.00) \\
58599\end{array}$ & $\begin{array}{l}--- \\
--- \\
--- \\
\end{array}$ \\
\hline \multicolumn{7}{|c|}{ Results without lost observations } \\
\hline $\begin{array}{l}\text { Cohort } 3 \\
(1996)\end{array}$ & $\begin{array}{l}\text { Coefficient } \\
\text { (s.e.) } \\
\text { Observations }\end{array}$ & $\begin{array}{l}0.19 * * \\
(0.02) \\
63425\end{array}$ & $\begin{array}{l}0.20 * * \\
(0.02) \\
63621\end{array}$ & $\begin{array}{l}0.18 * * \\
(0.02) \\
63937\end{array}$ & $\begin{array}{l}0.18^{* \star} \\
(0.02) \\
63240\end{array}$ & $\begin{array}{l}0.13^{* *} \\
(0.02) \\
57890\end{array}$ \\
\hline $\begin{array}{l}\text { Cohort } 4 \\
\text { (1995) }\end{array}$ & $\begin{array}{l}\text { Coefficient } \\
\text { (s.e.) } \\
\text { Observations }\end{array}$ & $\begin{array}{l}0.23^{* *} \\
(0.02) \\
64037\end{array}$ & $\begin{array}{l}0.21 * * \\
(0.02) \\
64003\end{array}$ & $\begin{array}{l}0.17 * * \\
(0.02) \\
62735\end{array}$ & $\begin{array}{l}0.09 * * \\
(0.02) \\
58557\end{array}$ & $\begin{array}{l}0.11 * * \\
(0.02) \\
54669\end{array}$ \\
\hline $\begin{array}{l}\text { Cohort } 5 \\
(1994)\end{array}$ & $\begin{array}{l}\text { Coefficient } \\
\text { (s.e.) } \\
\text { Observations }\end{array}$ & $\begin{array}{l}0.17 * * \\
(0.02) \\
62673\end{array}$ & $\begin{array}{l}0.15^{\star *} \\
(0.02) \\
60941\end{array}$ & $\begin{array}{l}0.09 * * \\
(0.02) \\
58700\end{array}$ & $\begin{array}{l}0.08^{* *} \\
(0.02) \\
51945\end{array}$ & $\begin{array}{l}0.05^{* *} \\
(0.02) \\
47305\end{array}$ \\
\hline $\begin{array}{l}\text { Cohort } 6 \\
\text { (1993) }\end{array}$ & $\begin{array}{l}\text { Coefficient } \\
\text { (s.e.) } \\
\text { Observations }\end{array}$ & $\begin{array}{l}0.22 * * \\
(0.02) \\
58599\end{array}$ & $\begin{array}{l}0.09 * * \\
(0.02) \\
54887\end{array}$ & $\begin{array}{l}0.12^{* *} \\
(0.02) \\
51390\end{array}$ & $\begin{array}{l}0.06^{* *} \\
(0.02) \\
44653 \\
\end{array}$ & $\begin{array}{l}--- \\
--- \\
---\end{array}$ \\
\hline
\end{tabular}

Note: Two-stage least squares regressions of a binary indicator for attending grammar school on school entry age, instrumented by assigned school entry age. ${ }^{*}$ Significant at the 10 percent level. ${ }^{*}$ Significant at the 5 percent level. Documented coefficients refer to specifications without control variables. Effects are robust if available control variables (gender, region, and nationality) are considered. The upper panel of the estimates includes simulation results holding the number of observations constant for grades 10 to 13 (see Section 3.3). Missing observations are assumed to be lower track students since they would be in the data if they had sought a higher secondary diploma. The lower panel of the estimates shows the results based only on observed students without simulated observations.

Source: Student-level data of the statistics on general and vocational schools for the state of Hessen 2002/03 to 2006/07 provided by the Hessen State Statistical Office (Hessisches Statistisches Landesamt). Authors' own calculations. 
Table A5: Second-Stage Results for a Change-to-Grammar-School Outcome-Full Population of Students

\begin{tabular}{|c|c|c|c|c|c|c|}
\hline $\begin{array}{l}\text { Cohort } 1 \\
(1998)\end{array}$ & $\begin{array}{l}\text { Coefficient } \\
\text { (s.e.) } \\
\text { Observations }\end{array}$ & $\begin{array}{l}2002 / 03 \\
0.15^{\star *} \\
(0.01) \\
62757\end{array}$ & $\begin{array}{l}2003 / 04 \\
0.03^{* *} \\
(0.00) \\
61368\end{array}$ & $\begin{array}{l}2004 / 05 \\
0.01 \\
(0.01) \\
61505\end{array}$ & $\begin{array}{l}2005 / 06 \\
0.00 \\
(0.00) \\
61347\end{array}$ & $\begin{array}{l}2006 / 07 \\
0.00 \\
(0.00) \\
61947\end{array}$ \\
\hline $\begin{array}{l}\text { Cohort } 2 \\
\text { (1997) }\end{array}$ & $\begin{array}{l}\text { Coefficient } \\
\text { (s.e.) } \\
\text { Observations }\end{array}$ & $\begin{array}{l}0.04^{* *} \\
(0.01) \\
59125\end{array}$ & $\begin{array}{l}0.00 \\
(0.01) \\
59781\end{array}$ & $\begin{array}{l}0.01 * * \\
(0.00) \\
60087\end{array}$ & $\begin{array}{l}0.00 \\
(0.00) \\
60882\end{array}$ & $\begin{array}{l}0.00 * \\
(0.00) \\
59628\end{array}$ \\
\hline $\begin{array}{l}\text { Cohort } 3 \\
\text { (1996) }\end{array}$ & $\begin{array}{l}\text { Coefficient } \\
\text { (s.e.) } \\
\text { Observations }\end{array}$ & $\begin{array}{l}-0.01 \\
(0.01) \\
63391\end{array}$ & $\begin{array}{l}0.04^{* *} \\
(0.00) \\
63577\end{array}$ & $\begin{array}{l}0.00 * \\
(0.00) \\
63913\end{array}$ & $\begin{array}{l}0.00 \\
(0.00) \\
63224\end{array}$ & $\begin{array}{l}-0.11^{* *} \\
(0.02) \\
63224\end{array}$ \\
\hline $\begin{array}{l}\text { Cohort } 4 \\
\text { (1995) }\end{array}$ & $\begin{array}{l}\text { Coefficient } \\
\text { (s.e.) } \\
\text { Observations }\end{array}$ & $\begin{array}{l}0.04 * * \\
(0.00) \\
63992\end{array}$ & $\begin{array}{l}0.00 \\
(0.00) \\
63960\end{array}$ & $\begin{array}{l}0.00 * \\
(0.00) \\
62731\end{array}$ & $\begin{array}{l}-0.07^{* *} \\
(0.01) \\
62731\end{array}$ & $\begin{array}{l}-0.02^{*} \\
(0.01) \\
62731\end{array}$ \\
\hline $\begin{array}{l}\text { Cohort } 5 \\
(1994)\end{array}$ & $\begin{array}{l}\text { Coefficient } \\
\text { (s.e.) } \\
\text { Observations }\end{array}$ & $\begin{array}{l}0.00 \\
(0.00) \\
62641\end{array}$ & $\begin{array}{l}0.00 \\
(0.00) \\
60913\end{array}$ & $\begin{array}{l}-0.07^{* *} \\
(0.01) \\
60913\end{array}$ & $\begin{array}{l}-0.02^{* *} \\
(0.01) \\
60913\end{array}$ & $\begin{array}{l}-0.02^{* *} \\
(0.01) \\
60913\end{array}$ \\
\hline $\begin{array}{l}\text { Cohort } 6 \\
(1993)\end{array}$ & $\begin{array}{l}\text { Coefficient } \\
\text { (s.e.) } \\
\text { Observations }\end{array}$ & $\begin{array}{l}0.00 \\
(0.00) \\
58569 \\
\end{array}$ & $\begin{array}{l}-0.08^{* *} \\
(0.01) \\
58569\end{array}$ & $\begin{array}{l}-0.01 \\
(0.01) \\
58569\end{array}$ & $\begin{array}{l}-0.01 \\
(0.01) \\
58569\end{array}$ & $\begin{array}{l}--- \\
--- \\
--- \\
\end{array}$ \\
\hline & \multicolumn{6}{|c|}{ Results without lost observations } \\
\hline $\begin{array}{l}\text { Cohort } 3 \\
(1996)\end{array}$ & $\begin{array}{l}\text { Coefficient } \\
\text { (s.e.) } \\
\text { Observations }\end{array}$ & $\begin{array}{l}-0.01 \\
(0.01) \\
63391\end{array}$ & $\begin{array}{l}0.04^{* *} \\
(0.00) \\
63577\end{array}$ & $\begin{array}{l}0.00 * \\
(0.00) \\
63913\end{array}$ & $\begin{array}{l}0.00 \\
(0.00) \\
63224\end{array}$ & $\begin{array}{l}-0.11^{* *} \\
(0.02) \\
57890\end{array}$ \\
\hline $\begin{array}{l}\text { Cohort } 4 \\
(1995)\end{array}$ & $\begin{array}{l}\text { Coefficient } \\
\text { (s.e.) } \\
\text { Observations }\end{array}$ & $\begin{array}{l}0.04^{* *} \\
(0.00) \\
63992\end{array}$ & $\begin{array}{l}0.00 \\
(0.00) \\
63960\end{array}$ & $\begin{array}{l}0.00 * \\
(0.00) \\
62731\end{array}$ & $\begin{array}{l}-0.08^{* *} \\
(0.02) \\
58552\end{array}$ & $\begin{array}{l}-0.01 \\
(0.01) \\
54669\end{array}$ \\
\hline $\begin{array}{l}\text { Cohort } 5 \\
(1994)\end{array}$ & $\begin{array}{l}\text { Coefficient } \\
\text { (s.e.) } \\
\text { Observations }\end{array}$ & $\begin{array}{l}0.00 \\
(0.00) \\
62641\end{array}$ & $\begin{array}{l}0.00 \\
(0.00) \\
60913\end{array}$ & $\begin{array}{l}-0.08^{* *} \\
(0.02) \\
58693\end{array}$ & $\begin{array}{l}-0.02 * \\
(0.01) \\
51939\end{array}$ & $\begin{array}{l}-0.02^{* *} \\
(0.01) \\
47305\end{array}$ \\
\hline $\begin{array}{l}\text { Cohort } 6 \\
(1993)\end{array}$ & $\begin{array}{l}\text { Coefficient } \\
\text { (s.e.) } \\
\text { Observations }\end{array}$ & $\begin{array}{l}0.00 \\
(0.00) \\
58569\end{array}$ & $\begin{array}{l}-0.10^{* *} \\
(0.02) \\
54884\end{array}$ & $\begin{array}{l}0.00 \\
(0.01) \\
51390\end{array}$ & $\begin{array}{l}-0.01 \\
(0.01) \\
44653\end{array}$ & $\begin{array}{l}--- \\
--- \\
---\end{array}$ \\
\hline
\end{tabular}

Note: Two-stage least squares regressions of a binary indicator for upgrading to grammar school on school entry age, instrumented by assigned school entry age. Grammar school students are included in the regressions, although they cannot upgrade, to make the coefficients comparable with changes in coefficients of regressions with attending grammar school as the outcome variable. * Significant at the 10 percent level. ** Significant at the 5 percent level. Documented coefficients refer to specifications without control variables. Effects are robust if available control variables (gender, region, and nationality) are considered. The upper panel of the estimates includes simulation results holding the number of observations constant for grades 10 to 13 (see Section 3.3). Missing observations are assumed to be lower track students since they would be in the data if they had sought a higher secondary diploma. The lower panel of the estimates shows the results based only on observed students without simulated observations.

Source: Student-level data of the statistics on general and vocational schools for the state of Hessen 2002/03 to 2006/07 provided by the Hessen State Statistical Office (Hessisches Statistisches Landesamt). Authors' own calculations. 
Table A6: Second-Stage Results-Population of Male Students Born in June or July

\begin{tabular}{|c|c|c|c|c|c|c|}
\hline & & $2002 / 03$ & $2003 / 04$ & $2004 / 05$ & $2005 / 06$ & $2006 / 07$ \\
\hline \multirow{3}{*}{$\begin{array}{l}\text { Cohort } 1 \\
\text { (1998) }\end{array}$} & Coefficient & $0.15^{\star *}$ & $0.14^{\star *}$ & $0.14^{* *}$ & $0.11^{* *}$ & $0.10^{* *}$ \\
\hline & (s.e.) & (0.03) & $(0.03)$ & $(0.04)$ & $(0.04)$ & $(0.04)$ \\
\hline & Observations & 5553 & 5369 & 5407 & 5411 & 5279 \\
\hline \multirow{3}{*}{$\begin{array}{l}\text { Cohort } 2 \\
\text { (1997) }\end{array}$} & Coefficient & $0.08^{* *}$ & $0.09^{* *}$ & $0.08^{* *}$ & $0.07^{* *}$ & $0.07^{* *}$ \\
\hline & (s.e.) & $(0.03)$ & (0.03) & (0.03) & $(0.03)$ & $(0.03)$ \\
\hline & Observations & 5229 & 5282 & 5299 & 5329 & 5092 \\
\hline \multirow{3}{*}{$\begin{array}{l}\text { Cohort } 3 \\
\text { (1996) }\end{array}$} & Coefficient & $0.16^{* *}$ & $0.14^{* *}$ & $0.13^{* *}$ & $0.17^{* *}$ & $0.10^{*}$ \\
\hline & (s.e.) & $(0.04)$ & $(0.04)$ & $(0.04)$ & $(0.04)$ & $(0.05)$ \\
\hline & Observations & 5586 & 5587 & 5634 & 5528 & 5528 \\
\hline \multirow{2}{*}{$\begin{array}{l}\text { Cohort } 4 \\
\text { (1995) }\end{array}$} & $\begin{array}{l}\text { Coefficient } \\
\text { (s.e.) }\end{array}$ & $\begin{array}{l}0.17^{* *} \\
(0.05)\end{array}$ & $\begin{array}{l}0.13^{* *} \\
(0.04)\end{array}$ & $\begin{array}{l}0.14^{* *} \\
(0.05)\end{array}$ & $\begin{array}{l}0.06 \\
(0.05)\end{array}$ & $\begin{array}{l}0.00 \\
(0.05)\end{array}$ \\
\hline & Observations & 5579 & 5555 & 5396 & 5396 & 5396 \\
\hline \multirow{3}{*}{$\begin{array}{l}\text { Cohort } 5 \\
(1994)\end{array}$} & Coefficient & $0.14^{* *}$ & $0.14^{* *}$ & $0.09^{*}$ & 0.02 & 0.05 \\
\hline & (s.e.) & $(0.04)$ & $(0.04)$ & $(0.05)$ & $(0.05)$ & $(0.04)$ \\
\hline & Observations & 5492 & 5226 & 5226 & 5226 & 5226 \\
\hline \multirow{4}{*}{$\begin{array}{l}\text { Cohort } 6 \\
\text { (1993) }\end{array}$} & Coefficient & $0.13^{* *}$ & 0.00 & 0.00 & 0.04 & --- \\
\hline & (s.e.) & $(0.04)$ & $(0.04)$ & $(0.04)$ & $(0.04)$ & --- \\
\hline & Observations & 5252 & 5252 & 5252 & 5252 & --- \\
\hline & Results with & t lost obs & tions & & & \\
\hline \multirow{3}{*}{$\begin{array}{l}\text { Cohort } 3 \\
\text { (1996) }\end{array}$} & Coefficient & $0.16^{* *}$ & $0.14^{* *}$ & $0.13^{* *}$ & $0.17^{* *}$ & $0.14^{* *}$ \\
\hline & (s.e.) & $(0.04)$ & $(0.04)$ & $(0.04)$ & $(0.04)$ & $(0.05)$ \\
\hline & Observations & 5586 & 5587 & 5634 & 5528 & 4984 \\
\hline \multirow{3}{*}{$\begin{array}{l}\text { Cohort } 4 \\
\text { (1995) }\end{array}$} & Coefficient & $0.17^{* *}$ & $0.13^{* *}$ & $0.14^{* *}$ & 0.08 & 0.06 \\
\hline & (s.e.) & $(0.05)$ & $(0.04)$ & $(0.05)$ & $(0.05)$ & $(0.05)$ \\
\hline & Observations & 5579 & 5555 & 5396 & 4993 & 4653 \\
\hline \multirow{3}{*}{$\begin{array}{l}\text { Cohort } 5 \\
\text { (1994) }\end{array}$} & Coefficient & $0.14^{* *}$ & $0.14^{* *}$ & $0.12^{* *}$ & $0.09^{*}$ & 0.07 \\
\hline & (s.e.) & $(0.04)$ & $(0.04)$ & $(0.05)$ & $(0.05)$ & $(0.05)$ \\
\hline & Observations & 5492 & 5226 & 5159 & 4553 & 4160 \\
\hline \multirow{3}{*}{$\begin{array}{l}\text { Cohort } 6 \\
\text { (1993) }\end{array}$} & Coefficient & $0.13^{* *}$ & 0.05 & $0.10^{* *}$ & 0.06 & --- \\
\hline & (s.e.) & $(0.04)$ & $(0.04)$ & $(0.05)$ & $(0.05)$ & --- \\
\hline & Observations & 5252 & 4903 & 4460 & 4025 & --- \\
\hline
\end{tabular}

Note: Two-stage least squares regressions of a binary indicator for attending grammar school on school entry age, instrumented by assigned school entry age. *Significant at the 10 percent level. ** Significant at the 5 percent level. Documented coefficients refer to specifications without control variables. Effects are robust if available control variables (gender, region, and nationality) are considered. The upper panel of the estimates includes simulation results holding the number of observations constant for grades 10 to 13 (see Section 3.3). Missing observations are assumed to be lower track students since they would be in the data if they had sought a higher secondary diploma. The lower panel of the estimates shows the results based only on observed students without simulated observations.

Source: Student-level data of the statistics on general and vocational schools for the state of Hessen 2002/03 to 2006/07 provided by the Hessen State Statistical Office (Hessisches Statistisches Landesamt). Authors' own calculations. 
Table A7: Second-Stage Results-Population of Female Students born in June or July

\begin{tabular}{|c|c|c|c|c|c|c|}
\hline & & $2002 / 03$ & $2003 / 04$ & $2004 / 05$ & $2005 / 06$ & $2006 / 2007$ \\
\hline \multirow{3}{*}{$\begin{array}{l}\text { Cohort } 1 \\
\text { (1998) }\end{array}$} & Coefficient & $0.11^{* *}$ & $0.16^{* \star}$ & $0.18^{* *}$ & $0.18^{* *}$ & $0.13^{* *}$ \\
\hline & (s.e.) & $(0.04)$ & $(0.03)$ & $(0.04)$ & $(0.04)$ & $(0.04)$ \\
\hline & Observations & 5537 & 5421 & 5443 & 5443 & 5351 \\
\hline \multirow{3}{*}{$\begin{array}{l}\text { Cohort } 2 \\
\text { (1997) }\end{array}$} & Coefficient & $0.11^{* *}$ & $0.09^{* *}$ & $0.08^{* *}$ & $0.08^{* *}$ & $0.08^{* *}$ \\
\hline & (s.e.) & $(0.04)$ & $(0.04)$ & $(0.04)$ & $(0.04)$ & $(0.04)$ \\
\hline & Observations & 5106 & 5135 & 5181 & 5181 & 5100 \\
\hline \multirow{3}{*}{$\begin{array}{l}\text { Cohort } 3 \\
\text { (1996) }\end{array}$} & Coefficient & $0.11^{* *}$ & $0.12^{* *}$ & $0.11^{* *}$ & $0.11^{* *}$ & 0.00 \\
\hline & (s.e.) & $(0.04)$ & $(0.04)$ & $(0.04)$ & $(0.04)$ & (0.05) \\
\hline & Observations & 5340 & 5360 & 5415 & 5415 & 5377 \\
\hline \multirow{3}{*}{$\begin{array}{l}\text { Cohort } 4 \\
\text { (1995) }\end{array}$} & Coefficient & $0.20^{* *}$ & $0.16^{* *}$ & $0.14^{* *}$ & 0.07 & $0.07^{*}$ \\
\hline & (s.e.) & $(0.05)$ & $(0.05)$ & $(0.05)$ & $(0.05)$ & $(0.04)$ \\
\hline & Observations & 5485 & 5532 & 5392 & 5392 & 5392 \\
\hline \multirow{3}{*}{$\begin{array}{l}\text { Cohort } 5 \\
(1994)\end{array}$} & Coefficient & $0.13^{* *}$ & $0.13^{* *}$ & 0.07 & 0.01 & -0.06 \\
\hline & (s.e.) & $(0.04)$ & $(0.04)$ & $(0.04)$ & $(0.04)$ & $(0.04)$ \\
\hline & Observations & 5261 & 5174 & 5174 & 5174 & 5174 \\
\hline \multirow{4}{*}{$\begin{array}{l}\text { Cohort } 6 \\
\text { (1993) }\end{array}$} & Coefficient & $0.18^{* *}$ & 0.04 & -0.06 & -0.01 & --- \\
\hline & (s.e.) & (0.05) & (0.05) & $(0.05)$ & $(0.05)$ & --- \\
\hline & Observations & 5001 & 5001 & 5001 & 5001 & --- \\
\hline & Results witho & t lost obs & tions & & & \\
\hline \multirow{3}{*}{$\begin{array}{l}\text { Cohort } 3 \\
\text { (1996) }\end{array}$} & Coefficient & $0.11^{\text {**}}$ & $0.12^{* *}$ & $0.11^{* *}$ & $0.11^{* *}$ & 0.07 \\
\hline & (s.e.) & $(0.04)$ & $(0.04)$ & $(0.04)$ & $(0.04)$ & $(0.05)$ \\
\hline & Observations & 5340 & 5360 & 5415 & 5415 & 4869 \\
\hline \multirow{3}{*}{$\begin{array}{l}\text { Cohort } 4 \\
\text { (1995) }\end{array}$} & Coefficient & $0.20^{* *}$ & $0.16^{* *}$ & $0.14^{* *}$ & $0.10^{* *}$ & $0.08^{*}$ \\
\hline & (s.e.) & $(0.05)$ & $(0.05)$ & $(0.05)$ & $(0.05)$ & $(0.05)$ \\
\hline & Observations & 5485 & 5532 & 5392 & 5008 & 4692 \\
\hline \multirow{3}{*}{$\begin{array}{l}\text { Cohort } 5 \\
\text { (1994) }\end{array}$} & Coefficient & $0.13^{* *}$ & $0.13^{* *}$ & $0.08^{*}$ & 0.06 & 0.03 \\
\hline & (s.e.) & $(0.04)$ & $(0.04)$ & $(0.04)$ & $(0.05)$ & $(0.05)$ \\
\hline & Observations & 5261 & 5174 & 4895 & 4319 & 3926 \\
\hline \multirow{3}{*}{$\begin{array}{l}\text { Cohort } 6 \\
\text { (1993) }\end{array}$} & Coefficient & $0.18^{* *}$ & 0.03 & 0.07 & 0.01 & --- \\
\hline & (s.e.) & $(0.05)$ & (0.05) & $(0.05)$ & $(0.05)$ & --- \\
\hline & Observations & 5001 & 4561 & 4262 & 3787 & --- \\
\hline
\end{tabular}

Note: Two-stage least squares regressions of a binary indicator for attending grammar school on school entry age, instrumented by assigned school entry age. *Significant at the 10 percent level. ${ }^{*}$ Significant at the 5 percent level. Documented coefficients refer to specifications without control variables. Effects are robust if available control variables (gender, region, and nationality) are considered. The upper panel of the estimates includes simulation results holding the number of observations constant for grades 10 to 13 (compare section 3.3). Missing observations are assumed to be lower track students since they would be in the data if they had sought a higher secondary diploma. The lower panel of the estimates shows the results based only on observed students without simulated observations.

Source: Student-level data of the statistics on general and vocational schools for the state of Hessen 2002/03 to 2006/07 provided by the Hessen State Statistical Office (Hessisches Statistisches Landesamt). Authors' own calculations. 